\title{
Characterising and Modelling the Excavation Damaged Zone (EDZ) in Crystalline Rock in the Context of Radioactive Waste Disposal
}

\author{
J A Hudson ${ }^{1 *}$, A Bäckström², J Rutqvist $^{3}$, L Jing $^{4}$ \\ T Backers $^{5}$, M Chijimatsu ${ }^{6}$, R Christiansson ${ }^{7}$, X-T Feng $^{8}$, A Kobayashi ${ }^{9}$, T Koyama ${ }^{4,9}$, \\ H-S Lee ${ }^{10}$, I Neretnieks ${ }^{4}$, P-Z Pan ${ }^{8}$, M Rinne ${ }^{11}$, B-T Shen ${ }^{12}$ \\ ${ }^{1}$ Imperial College, UK \\ ${ }^{2}$ Berg Bygg Konsult AB and Royal Institute of Technology, Stockholm, Sweden \\ ${ }^{3}$ Lawrence Berkeley National Laboratory, Earth Sciences Division, Berkeley, California, \\ USA \\ ${ }^{4}$ Royal Institute of Technology, Stockholm, Sweden, \\ ${ }^{5}$ GeoFrames GmbH, Germany, \\ ${ }^{6}$ Hazama Cooperation, Japan \\ ${ }^{7}$ SKB, Sweden \\ ${ }^{8}$ State Key Laboratory of Geomechanics and Geotechnical Engineering, Institute of Rock and \\ Soil Mechanics, Chinese Academy of Sciences, China

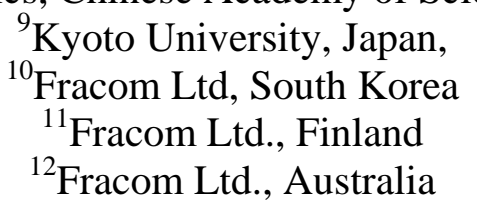

*john.a.hudson@gmail.com

\section{Abstract}

This paper describes current knowledge about the nature of and potential for thermo-hydromechanical-chemical modelling of the Excavation Damaged Zone (EDZ) around the excavations for an underground radioactive waste repository. In the first part of the paper, the disturbances associated with excavation are explained, together with reviews of Workshops that have been held on the subject. In the second part of the paper, the results of a DECOVALEX $^{1}$ research programme on modelling the EDZ are presented. Four research teams used four different models to simulate the complete stress-strain curve for Avro granite from the Swedish Äspö Hard Rock Laboratory. Subsequent research extended the work to computer simulation of the evolution of the repository using a 'wall block model' and a 'near-field model'. This included assessing the evolution of stress, failure and permeability and time dependent effects during repository evolution. As discussed, all the computer models are well suited to sensitivity studies for evaluating the influence of their respective supporting parameters on the complete stress-strain curve for rock and for modelling the EDZ.

Keywords: rock mechanics, radioactive waste, excavation disturbed zone, characterisation, modelling

\footnotetext{
${ }^{1}$ DEmonstration of COupled models and their VALidation against EXperiment: Research funded by an international consortium of radioactive waste regulators and implementers (www. decovalex.com).
} 


\section{Introduction}

The Excavation Damaged Zone (EDZ) is the rock zone around an underground excavation where irreversible changes have taken place. Such a zone is inevitable because of the changed conditions resulting from the removal of rock during the construction process. Further into the rock is an Excavation Disturbed Zone (EdZ) in which changes associated with construction are reversible.

The purpose of this paper is to describe the occurrence, nature and evolution of the Excavation Damaged Zone (EDZ) in the context of a radioactive waste repository in crystalline rock with emphasis on the characterisation and modelling processes. The content is based on Task B of the DECOVALEX-THMC research project which took place from 2004 to 2007. The objective of this research project was to improve understanding of the evolution of the EDZ and to be able to numerically model the EDZ HMC mechanisms in a fractured crystalline rock mass. A deeper understanding of the EDZ was developed through understanding the driving forces, the couplings including $\mathrm{C}$, the evolution through excavation, emplacement and closure, and a greater ability to explicitly incorporate the EDZ in PA/SA assessments. There were studies of the crack/fracture evolution, the distinction between the mechanical and flow EDZs, establishing to what extent a coupled model is required, establishing how to cope with uncertainties, and utilizing data available from the Äspö HRL.

The document can therefore be regarded as a Guidance Document on characterising and modelling the EDZ, although it is only possible here to provide an overview of the subject with examples.

\section{Part 1: Characterising the EDZ}

In order to introduce the EDZ subject further, the following sub-sections discuss the phenomenon of the Excavation Damaged Zone, reviews of the EDZ and related aspects, factors relating to the EDZ, the rock mass response to tunnelling, the excavation method, and EDZ characterisation methods.

\section{The phenomenon of the Excavation Damaged Zone}

The Excavation Disturbed Zone (EdZ) and Excavation Damaged Zone (EDZ) are the perturbed rock zones around an underground opening following excavation. These zones occur because of the inevitable effects of excavation, and the effects will be exacerbated to a greater or lesser extent by the excavation mode, i.e. whether by blasting or by the use of a tunnel boring machine.

Figure 1(a) shows the sidewall of a tunnel at the Äspö Hard Rock Laboratory, Sweden, where sections of the wall have been diamond sawn out of the granite and Figure 1(b) shows the type of fracturing that can occur in the EDZ region. In this case, some of the fracturing has clearly been induced by blasting because the cracking initiates from the visible half- 
barrels of the blastholes, Figure 1(b). This is one of the many methods described later in this document for assessing the damage to the EDZ.

The formation of some form of EdZ and EDZ is inevitable. This is because the three primary effects of excavation are (Hudson and Harrison 1997):

(a) displacements occur because stressed rock has been removed, allowing the remaining rock to move (due to unloading);

(b) there are no normal and shear stresses on an unsupported excavation surface and hence the excavation boundary must be a principal stress plane with one of the principal stresses (of magnitude zero) being normal to the surface. Generally, this will involve a major perturbation of the pre-existing stress field, both in the principal stress magnitudes and their orientations; and

(c) at the boundary of an excavation open to the atmosphere, any previous fluid pressure existing in the rock mass will be reduced to zero (or more strictly, to atmospheric pressure). This causes the excavation to act as a 'sink', and any fluid within the rock mass will tend to flow into the excavation.

The magnitudes of the effects will depend on the rock mass circumstances, the method of excavation and any mitigating strategies used in the rock engineering. The main concern in the radioactive waste context is the potential creation of new fractures and/or the opening of existing fractures that can contribute to enhanced fracture connectivity and hence increase the rock mass permeability and associated potential radionuclide migration via increased water flow.

\section{Reviews of the EDZ and related aspects}

There is a large body of research literature available on the EDZ. In this review, we will concentrate initially on summarising the essence of the second of two EDZ Workshops held in Canada, the first being in 1996 in Winnipeg (Martino and Martin 1996) and the second in 2002 in Toronto (Martino 2003). Then, the proceedings of a European Commission Cluster EDZ Conference and Workshop held in Luxembourg in 2003 (Davies and Bernier 2005) will be reviewed. Finally, the content of a review paper by Tsang (2005) will be abstracted.

\section{Canadian EDZ Workshop held in 2002}

At this international Workshop, 14 papers on various aspects of the EDZ were presented. Following the presentation of the papers and the Workshop discussion, the following points were made.

- The EDZ must be considered as part of the repository system

- The EDZ, backfill and interfaces need to be considered in the sealing system

- The influence of thermal effects on the EDZ, backfill and interfaces in the sealing system need to be considered

- The EDZ evolution with time as conditions change needs to be considered

- There is a question about the importance of the EDZ at all locations in the repository

- The role of the EDZ in the potential radionuclide transport pathway needs to be evaluated

- Research is required into the development of the EDZ in different rock types 
- Some EDZ characterisation tools need refinement

\section{European Commission Cluster EDZ Conference and Workshop held in 2003}

The title of this conference and workshop was "Impact of the Excavation Disturbed or Damaged Zone (EDZ) on the Performance of Radioactive Waste Geological Repositories" (see Davies and Bernier 2005). The purpose of the meeting was to

- To establish the state of the art of the EDZ

- To assess its impact on the performance of geological repositories

- To propose possible remedial actions to the EDZ for different repository stages. The conference covered plastic and indurated clays, crystalline rock and salt. The proceedings include a large amount of material addressing: what is the EDZ?; how is the EDZ created and controlled?; how does the EDZ evolve?; what is the impact of EDZ on performance and safety?; what can be done about it?; and what is the state of knowledge and uncertainties?

In the Working Group Report (Davies and Bernier 2005) on the EDZ in crystalline rocks, on pages 37-40 it is noted that the EDZ does not have any extra impact on the operational safety of repositories but, for long-term performance, the EDZ pathway may be important. It is also noted in this context that special weight should be given to hydro-thermo-mechanical couplings. In giving an assessment of the state of knowledge and uncertainties, the text states that "At the moment, we know the development and extent of the EDZ in different crystalline rock formations relatively well. In addition, hydraulic behaviour is quite well known just after the formation of the primary EDZ. Long-term behaviour and different extension/sealing processes are theoretically quite well known, but their relative strengths and time periods are quite unknown.”

Of particular interest, also in Davies and Bernier 2005, is a review (pages 77-89) of the conclusions of previous EDZ Workshops and a review (pages 91-111) on lessons learned with respect to the EDZ in crystalline rock.

\section{Review paper by Tsang, Bernier and Davies (2005)}

The paper by Tsang et al. (2005) on geohydromechanical processes in the EDZ in crystalline rock, rock salt, and indurated and plastic clays contains a synthesis of the European Commission Cluster EDZ Conference and Workshop described above. The paper contains proposed definitions for the Excavation disturbed Zone and Excavation Damaged Zone as follows:

- the EdZ is a zone with hydromechanical and geochemical modifications, without major changes in flow and transport properties; and

- The EDZ is a zone in which hydromechanical and geochemical modifications induce significant changes in flow and transport properties. These changes can, for example, include one or more orders-of-magnitude increase in flow permeability.

The synthesis table considers the EDZ factors at the excavation stage, open drift stage, backfill and resaturation and heating stage, and late closure stage. The overall issues for the EDZ in crystalline rocks are listed as: potential connected fast flow paths in the EDZ; effect 
of EDZ on resaturation rate; water flow between EDZ and fracture zones intersecting drift; role of EDZ at tunnel intersections; assessment of impacts of thermo-hydro-chemical (THC) and thermo-hydro-biological (THB) processes; improved tunnel construction and support method to reduce EDZ; optimal depth and orientation of tunnels relative to in situ stress condition and fracture/fault directions; design of methods to cutoff/interrupt EDZ; methods to 'improve' rock-seal interface; operational rules to reduce geochemical changes; need for establishing acceptable methodologies for complete PA scoping, bounding and sensitivity studies on effects of EDZ (including presence of fracture zones closed to drift); need to establish and confirm EDZ cutoff strategies and effectiveness of seals.

\section{Factors relating to the EDZ}

The generation and evolution of the EDZ involves many factors, as illustrated in Figure 2. These fall into three main categories which are discussed in the three following sub-sections.

- The rock mass response to tunnelling, i.e. creation of the inevitable EDZ disturbance

- Excavation method (creation of the additional EDZ disturbance)

- Characterisation methods (required so that the EDZ can be specified and modelled as necessary.

\section{Rock mass response to tunnelling}

The rock mass response to tunnelling is in terms of the consequential displacements, alteration of the local stress state and water inflow. These responses are inevitable and hence unavoidable but their magnitudes will be affected by the following (Hudson and Harrison, 1997).

- Tunnel geometry: the magnitude of the concentrated stress around the tunnel will depend on its geometry; sharp corners produce high local stress concentrations; and larger tunnels will produce proportionately larger EDZs

- State of stress: the higher the regional stresses, the higher will be the stress concentrations around the tunnel, and hence the possibility of stress induced rock damage.

- Orientation of the tunnel: the stress concentrations around the tunnel will be greatest and least when the tunnel axis is perpendicular and parallel to the maximum principal stress component, respectively.

- Mechanical properties of the rock: higher displacements will be associated with softer and weaker or squeezing/swelling rocks

- Mechanical properties of the rock mass: similarly, if rock fractures are present, they will reduce the rock mass stiffness and strength and so also cause higher displacements into the tunnel.

- Proximate geological structures: these can affect the displacements, stress state and water inflow and hence locally increase the EDZ effects.

Thus, the magnitudes of these effects as they influence the EDZ, can be mitigated by judicious choice of tunnel shape, tunnel depth and tunnel orientation. 


\section{Excavation method}

The factors described above for the rock mass response refer to the inevitable EDZ disturbance. Factors relating to the excavation method (Figure 2), which also affect the severity of the EDZ via additional disturbances, can be modified to reduce their effects.

- $\quad$ Rock conditions and blasting: Depending on the requirements, the EDZ extent can be significantly reduced by prudent blast design and the associated application of strict quality control measures.

- Drilling precision: The blastholes have to be well drilled in order to ensure that the intended explosive effect is achieved via the blast design.

- Explosives: Different explosives have different characteristics and so it is important that the explosive used is matched to the rock type and blast design.

- Specific charge: This is the quantity of explosive required to displace a unit quantity of rock and so needs to be adjusted to the blast design.

- Detonation velocity: This must also be matched to the rock type and blast design; lower detonation velocities will cause less damage around the blastholes.

- Initiation: Different blast designs use different initiation methods and detonators with different delay times.

- Charging and decoupling: The method of charging the blastholes with explosive is also important; 'decoupling' refers to reducing the explosive stress wave magnitude by avoiding direct contact between the explosive and the rock in the blastholes

- $\quad$ Rock conditions and use of a TBM: To reduce any effect of the TBM inducing additional EDZ damage, the type of TBM and its operation must be harmonised to the rock conditions;

- Cutter head design: Different rock types require different types of cutters and interlacing of these cutters (picks, discs, buttons) on the TBM head so these should be optimally matched to the rock conditions.

- Cutter head forces: By adjusting both the TBM head torque and thrust to avoid unnecessary vibrations, efficient rock cutting is achieved and there will be less additional damage to the EDZ.

\section{Characterisation methods}

Thus, the EDZ is created both by the inevitable effects due to the removal of rock and the additional effects due to the method by which the rock is removed. We consider now how the extent of the EDZ can be characterised (Figure 2).

- Investigations in the tunnel: This refers to the direct and indirect assessment of the EDZ via measurements made on or from the tunnel rock surfaces.

- $\quad$ Survey of the contour (overbreaks): The amount of overbreak can be measured directly by different surveying techniques; this does not indicate the whole EDZ but is indicative of the effects of excavation.

- Observations of half-barrels: the half-barrel is the remaining half of the tunnel periphery blastholes; with good blasting these should be mostly all visible; hence, the percentage of half-barrels visible is a measure of the blasting effectiveness and hence is an indirect indicator of the EDZ.

- Mapping of induced fractures: By cutting slots in the tunnel periphery, it is possible to make direct observations of the induced factors and hence the visible extent of the EDZ. 
- Surface geophysics: By measuring the P-wave velocity along the tunnel wall at different geophone distances, at different locations, and in different directions, an indirect estimate of the EDZ can be obtained.

- Weir measurements: Through measurements of the water inflow, estimates of the hydraulic transmissivity can be obtained and comparisons made for different tunnel lengths.

- Borehole investigations: Measurements made in boreholes through the EDZ can provide more detailed information on the EDZ nature and properties.

- Occurrence of macroscopic fractures: These will be directly visible in borehole core or in borehole TV logging; smaller fractures can be identified through thin-section analyses.

- Borehole geophysics: There are several borehole geophysical techniques available for estimating the EDZ extent, e.g. P-wave velocity measurements along and between boreholes.

- Borehole hydraulic tests: These can provide useful information, not only on the transmissivity values, but also on the connectivity of EDZ-induced fractures between boreholes.

\section{Evolution of the EDZ}

In the Sections above, we have concentrated on the 'immediate' EDZ. However, given the extremely long design life of the repository, measured in thousands if not millions of years, compared to the $\sim 120$ years design life of the usual civil engineering structure, it is necessary to consider the evolution of the repository.

For the purposes of this study, three stages in the evolution of the EDZ were recognised.

Stage 1. Initial construction - which alters the mechanical, hydrological and chemical circumstances;

Stage 2. A period when the excavation is left open, when drying of the rock occurs, water flows through the rock fractures, and there can be chemical changes; and

Stage 3. After the canisters and backfill are emplaced, the temperature increases and equilibrium is re-established over a long time period.

In the period when the repository is open, this will involve time-dependent effects. Later, during and after emplacement, the rock will be subject to elevated temperatures due to canister heating which will affect the rock stresses and accelerate chemical reactions. In the even longer term, the additional effects caused by glacial loading and unloading have to also be taken into account. Reports on repository evolution have been produced by SKB (2006) and Posiva (2006).

\section{Time-dependent effects and stress redistribution}

There can be confusion concerning the meaning of the terms creep, stress relaxation, and fatigue (Hudson and Harrison, 1997). Creep is defined as increasing strain while the stress is held constant. Stress relaxation is defined as decreasing stress while the strain is held constant. In practice, and especially for the rock around an underground excavation, a rock element 
will be loaded via the stiffness of an adjacent element and so the time-dependent behaviour will be somewhere between the ideal conditions of creep and stress relaxation. Fatigue refers to an oscillation in the applied stress producing permanent strain.

The rock around the deposition tunnels and deposition holes is subject to a secondary stress state, i.e. to the altered state of stress around the excavation resulting from the concentration of the primary regional stresses. Stresses will have been concentrated and failure of the rock may have occurred in the EDZ in the form of spalling. The excavation-peripheral rock is then subject to these stresses for a long period of time, each rock element in the excavation periphery is loaded by another rock element.

\section{Thermal effects}

Heat emitting canisters will heat the whole repository further increasing the magnitudes of the overall stress components in the repository volume. These thermal stresses are further concentrated around the repository excavation, possibly causing further spalling.

Note that these thermal stresses can have high magnitudes. For example, assuming a $45^{\circ} \mathrm{C}$ temperature rise, a $9.5 \mathrm{E}-06 /{ }^{\circ} \mathrm{C}$ coefficient of linear expansion of the rock, and a 55 GPa rock modulus, the additional stress is $45 \times 9.5 \mathrm{E}-06 \times 55 \cong 23.5 \mathrm{MPa}$, which is then further concentrated around the excavations. Where, the rock stresses are already near the rock spalling strength, more extensive EDZ damage will result.

\section{Hydrogeological effects}

The main concern related to the EDZ is the possibility of enhanced fracture flow parallel to the tunnel excavations, see Figure 3, increasing the potential transport of radionuclides. Fractures formed in the EDZ could increase the overall fracture connectivity, especially if there were a pre-existing fracture set sub-parallel to the excavation.

\section{Chemical effects}

In this THMC DECOVALEX phase, and bearing in mind the long design life of the repository, there has been emphasis on the chemistry, the $\mathrm{C}$ in THMC. This involves consideration of the minerals in crystalline rocks, the contained waters in crystalline rocks, and the reactions between these. Additional aspects are the transport of water and reactants, the rates and time scales of reactions, and the interaction between melt water and salt water.

\section{$\underline{\text { Minerals present }}$}

These are listed below in the categories of rock forming minerals, secondary minerals and clay.

- Rock forming minerals - Alumino-silicates (very low solubilities)

Quartz $\quad \mathrm{SiO}_{2}$

K-Feldspar $\mathrm{KAlSi}_{3} \mathrm{O}_{4}$

Biotite $\quad \mathrm{KMgFe}_{2} \mathrm{AlSi}_{3} \mathrm{O}_{10}(\mathrm{OH})_{2}$ 
Plagioclase $\quad \mathrm{Na}{ }_{0.62} \mathrm{Ca}_{0.38} \mathrm{Al}_{1.38} \mathrm{Si}_{2.62} \mathrm{O}_{8}$

- Secondary (reactive) minerals

Carbonates $\mathrm{CaCO}_{3}$ (Mostly as a secondary mineral in fractures)

Sulphide minerals $\mathrm{FeS}_{2}$

Iron oxides $\quad \mathrm{Fe}_{3} \mathrm{O}_{4}, \mathrm{Fe}(\mathrm{OOH})$

- Clays (mostly in fractures formed by weathering)

Kaolinite

$\mathrm{Al}_{2} \mathrm{Si}_{2} \mathrm{O}_{5}(\mathrm{OH})_{4}$

Montmorillonite

$\mathrm{Al}_{2} \mathrm{Si}_{4} \mathrm{O}_{10}(\mathrm{OH})_{2}$

Gibbsite

$\mathrm{Al}(\mathrm{OH})_{3}$

\section{$\underline{\text { Basic reaction types }}$}

The basic reaction types are listed below.

- Weathering (neutralises acid, produces cat-ions)

K-Feldspar -> Kaolinite (slow reaction)

$2 \mathrm{KAlSi}_{3} \mathrm{O}_{4}+2 \mathrm{H}^{+}+9 \mathrm{H}_{2} \mathrm{O}->\mathrm{Al}_{2} \mathrm{Si}_{2} \mathrm{O}_{5}(\mathrm{OH})_{4}+2 \mathrm{~K}^{+}+4 \mathrm{H}_{2} \mathrm{SiO}_{4}$

- Calcite dissolution (neutralises acid)

(fast reaction)

$\mathrm{CaCO}_{3}+\mathrm{H}_{2} \mathrm{CO}_{3}->\mathrm{Ca}^{2+}+2 \mathrm{HCO}_{3}^{-}$

- Calcite Precipitation

$\mathrm{Ca}^{2+}+2 \mathrm{HCO}_{3}^{--}->\mathrm{CaCO}_{3}+\mathrm{H}_{2} \mathrm{O}+\mathrm{CO}_{2}(\mathrm{~g})$

- Redox reactions

Pyrite oxidation (generates acid) (fast reaction)

$\mathrm{FeS}_{2}+15 / 4 \mathrm{O}_{2}+7 / 2 \mathrm{H}_{2} \mathrm{O}->\mathrm{Fe}(\mathrm{OH})_{3}+2 \mathrm{SO}_{4}{ }^{2+}+4 \mathrm{H}^{+}$

- Brine $(\mathrm{NaCl})$ interactions

Sodium expels K, Ca, .. From K, Ca, ..minerals

- Pressure dissolution

Initially, the stagnant groundwaters are essentially in equilibrium with the rock, so it is necessary to consider any perturbations that can disturb the EDZ chemistry. These are the possibility of up-coning of brine during the construction phase (the open repository excavation acts as a sink), also inflow of 'acid' surface waters during the construction phase, intrusion of oxygen from air during construction, the buffer and backfill not being in chemical equilibrium with the rock, concrete gives off $\mathrm{OH}^{-}$, and organics (oil, wood, paper...) degrading to give off $\mathrm{CO}_{2}$.

However, the reactant has to reach the EDZ to react and the reaction products must be carried away or precipitate for the reactions to continue. In crystalline rocks, the flow tends to be in channels within the fractures and, despite the increased fracturing and fracture dilation in the 
EDZ itself, the flow is limited by the fracture transmissivities further back in the host rock mass. It is thought that the weathering by carbon dioxide $(\mathrm{pH})$ by water infiltration during construction will be negligible. Similarly, weathering by diffusion of $\mathrm{CO}_{2}$ from the drift and $\mathrm{K}$-feldspar reaction is also anticipated to be negligible.

It is concluded that there will be negligible weathering and oxidation of the rock matrix during the 30 years or so of the open repository but that fracture channels could acquire minor amounts of secondary minerals in their more open portions. Neither melt water nor salt water are very aggressive to rock forming minerals but there could be electrostatic effects at mineral surfaces. Also, any alkaline plume from concrete is probably of negligible significance for the EDZ properties. Moreover, although bentonite (used as the canister-rock buffer) contains large amounts of $\mathrm{Na}$ and $\mathrm{Ca}$ in ion exchange positions and can act as sources or sinks for cations in rock in contact with the bentonite, the effect is expected to be negligible.

Thus, the most important chemical effect is the precipitation and dissolution of minerals in the fracture channels affecting the transmissivities of the fractures.

\section{Uncertainties and limitations in measuring and characterising the EDZ}

In Part 2 of this paper, modelling case studies will be reviewed which depend on the accuracy with which the EDZ is characterised. Thus, having discussed the manifold aspects of the EDZ, we conclude Part 1 with a listing of uncertainties relating to characterisation of the EDZ via the different types of measurements, see Table 1.

\section{Part 2: Case studies of numerically modelling the EDZ region}

For rock engineering design, it is necessary to be able to predict the future - in the sense that the consequences of different design options must be evaluated so that a choice of the repository characteristics can be made, e.g. the depth and orientation of tunnels. To make the prediction, some form of model is required and, given the flexibility provided by computer models, the use of numerical modelling techniques is now the preferred technique.

Accordingly, if the influence of the EDZ is to be evaluated and incorporated into other design studies, a numerical model needs to be established for the THMC behaviour of the EDZ, both in the short and long terms. Two numerical modelling studies were therefore conducted:

- the first simulated the failure of a rock element in uniaxial compression; and

- the second simulated the evolution of a quarter section of a tunnel.

The first simulation was primarily aimed at establishing whether the complete failure of a rock element in uniaxial compression could successfully be modelled using computer models. In fact, the progressive failure of rock due to spalling in the excavation periphery is a complex process because of the single free surface and the incremental development of diametrically opposed notches on the tunnel surfaces at opposite ends of a tunnel diameter 
perpendicular to the maximum stress component. To establish the efficacy of different computer models, however, it was decided to test them on an analogous but somewhat simpler case: the failure of a rock specimen in uniaxial compression, which has the advantage for the DECOVALEX research that physical testing of the rock properties in this condition for comparison was much easier to conduct. The second simulation aimed at computer modelling of the long-term THMC coupled evolution of the EDZ. In this way, the efficacy and limitations of current numerical modelling as a tool to characterise the EDZ could be established.

\section{Modelling the mechanical behaviour of a rock element in uniaxial compression}

The capability and validity of four numerical models in modelling the complete process of microstructural breakdown during the uniaxial compressive failure of an initially intact crystalline rock element with and without saline porewater was undertaken. In addition, the results generated by each model were compared with the experimentally determined complete stress-strain curves for the Swedish Ävrö granite for different porewater conditions. In this way, it was possible to audit the models' adequacy for this particular simulation task. Moreover, the common and special features of the different modelling techniques could be established, together with an assessment of the advantages and disadvantages of the different modelling techniques, plus the validity of the modelling techniques. This then provides a check on the basic modelling capability before attempting more sophisticated modelling of the exact nature of rock spalling, fracture dilation, etc., which was not attempted in the current programme.

Four different modelling programs were used by four different modelling groups, and compared to experimental uniaxial compressive tests on Ävrö granite specimens obtained from the Äspö Hard Rock Laboratory in Sweden. The study concerned the understanding and characterization of the complete failure process of intact rock in uniaxial compression using different numerical models, physical testing with chemical effects and co-ordination of the results.

In the experimental tests to obtain the complete stress-strain curve for intact rock samples in uniaxial compression, the influence of the hydro-chemical environment (with emphasis on saline porewater) was also investigated. The capabilities and results of the numerical modelling using different codes were compared to each other and the physical test results in order to evaluate the benefits and drawbacks of the different approaches.

\section{Laboratory testing and results for the Ävrö granite}

A series of laboratory tests was performed to obtain the complete stress-strain curves and to address the chemical and time dependent influences on the mechanical strength of a crystalline intact rock. The tests were all conducted on Ävrö granite from the Äspö Hard Rock Laboratory (ÄHRL) in Sweden. From the modal analysis made on five of the specimens, they are mainly composed of feldspar, quartz and mica in the following percentages, $66 \%$, $25 \%$ and $6 \%$, respectively. 
In the first set of tests, uniaxial compression tests were performed for different hydrochemical influences with different salinity and saturation porewater environments. The 20 specimens were divided into four groups with five specimens in each group. The first group was composed of specimens that had been dried and the rest of the samples were saturated with fluids having different salinities. Group 2 specimens were saturated with distilled water, according to the ISRM Suggested Method (Fairhurst and Hudson 1999); whereas, the specimens in the two last groups were saturated with waters having a salinity of $0.68 \%$ (denoted 'formation water') and $10 \%$ (denoted 'saline water'). Most of the specimens were saturated for 90 days, but two of the specimens saturated with distilled water and three of the specimens saturated with formation water had a saturation time of only 40 days.

The compressive tests were performed using a servo-controlled testing machine having a maximum capacity of 1.5 MN. Special techniques were required to obtain the Class II behaviour exhibited by the Ävrö granite (in which the axial strain does not monotonically increase) and the initial control program was set to a radial strain rate of $0.025 \% / \mathrm{min}$. This rate was increased after reaching the post-peak region. The tests were carried out to the postpeak regime in order to study the mechanical behaviour of the rock during the cracking process.

The Ävrö granite was found to be extremely brittle, i.e. the descending portion of the complete stress-strain curve is close to the ascending portion, Figure 4, indicating that relatively little energy is required to continue the failure process. This is also reflected in the irregularity of the radial strain curves as the machine corrects for the individual rock failure events. On studying the individual curves, it was found that the post-peak behaviour, which follows Class II type behaviour in all the specimens tested, was also affected by the fluid composition, as evidenced by the slopes of the post-failure loci. The general trend is that the slopes of the failure loci for several of the samples subjected to saline water have a higher positive slope than those for the specimens from the other groups (Table 2). All of these results indicate that a saline solution causes the rock specimens to be less brittle, i.e. tending towards Class I behaviour (where the axial strain does monotonically increase in displacement).

The results from these tests, Table 2, show that the saturated specimens have a decrease in both elastic modulus and unconfined compressive strength (UCS) compared to the dry specimens. Moreover, it can be seen that specimens saturated with saline solution exhibit a larger decrease in elastic properties than the specimens saturated with distilled water when compared to the dry samples. The UCS of the specimens saturated with $0.68 \%$ or $10 \%$ saline solution are on average about $17 \%$ lower than the UCS of the dry samples. The salinity reduces the modulus and strength as to distilled water might be an indication of the effect of the salt at the crack tips affecting the crack tip surface energy and hence the stress required for crack propagation.

A second set of specimens was also subjected to uniaxial compression testing and the saturation recommendations of the standards were followed, but here the acoustic emission was also monitored during the structural breakdown of the samples. Some specimens were subjected to triaxial testing and indirect tensile tests (Brazilian tests) and some to study time dependency using 'Strain Rate Stepping' tests (controlled by constant axial displacement rate before the peak). The results from these tests indicated that the time to failure would decrease from about $270 \mathrm{MPa}$ to about $200 \mathrm{MPa}$ in 100 years of the Ävrö granite. 


\section{The four numerical methods used to simulate rock failure in uniaxial compression}

The four research teams and their numerical modelling techniques used for the simulations are listed in Table 3. In the following sub-sections, each of these simulation methods is described.

\section{The Elasto-Plastic Cellular Automaton (EPCA) simulation}

This model simulates the rock behaviour in 2-D. The rock specimen is divided into a system of cell elements and, to describe the heterogeneity of the rock matrix, the mechanical properties for each element, such as Poisson's ratio, Young's modulus cohesive strength etc., are distributed by characterising them with the Weibull probability density function. To describe the heterogeneity of the material, a homogeneity index $(m)$ is used. In the EPCA method, three control methods can be considered, i.e. stress loading, constant strain rate and the linear combination of stress and strain. To control the loading process for Class II behaviour during uniaxial compression, a linear combination of stress and strain was used for the control program as developed by Okubo and Nishimatsu, 1985. In each loading step, the cell state is updated according to the cellular automaton rule for updating. At each step, the updated stresses are substituted into the modified Mohr-Coulomb criterion to verify whether the strength criterion is met or not and hence if yielding of the cell element will occur. If the cell element yields, it follows a corresponding plastic strain according to the elasto-brittleplastic constitutive theory; otherwise, the external force is increased further. The stress and deformation distribution throughout the specimen model are then adjusted after each rupture to reach the equilibrium stage.

The EPCA method was also able to reproduce the Class II extremely brittle behaviour and it was found that the failure pattern is different in simulations with different seed parameters. Also, in this study, it was found that the resulting compressive strength is more influenced by the homogeneity index than the seed number; whereas, the opposite applies for the actual failure mode of the rock.

\section{The Particle Flow Code (PFC)}

The rock material is represented as an assemblage of many small rigid circular particles bonded together with both non-linear (Hertz) contacts and linear contacts, although in this study the linear contact model was used. The central finite difference method, as applied in the distinct element method (DEM), is used to calculate the movement and interaction of each particle in this model. The linear contact model simulates an elastic relation between the relative displacement and contact force of particles.

In this method, the stage of back-calculation of micro-mechanical parameters (such as contact stiffness and strength at the grain boundaries) from the macro-parameters obtained from physical laboratory measurements is needed. These microscopic parameters are unique for every approach as they have to be obtained from the macroscopic mechanical parameters by a 
calibration of the particle model with identical boundary conditions. Therefore, an investigation of the representative elementary volume (REV) for the Ävrö granite was made to identify the proper particle size to use in this simulation. A micro-crack can be initiated by overcoming the stiffness of the bonds and hence causing breakage of the bond. Propagation is the progressive breakage of juxtaposed bonds.

When simulating the chemical degradation of the physical tests, all physical UCS tests were simulated individually. The microscopic parameters were calibrated for each group of specimens (subject to conditions of: dry, distilled, formation and saline hydro-chemical environment). The simulated specimen undergoes monotonic compression with controlled monotonic increase of axial strain without unloading or addition of lateral strain constraint; this means that Class II behaviour could not be modelled by PFC in this control mode. However, the complex degradation process can thus be simulated with the PFC approach (seen in Figure 5) including crack initiation, growth, coalescence, localization. The formation of multiple shear-band-like localized zones appear to be the main cause of damage and failure.

\section{The Displacement Discontinuity Method (DDM)}

In the FRACOD code, based on the Displacement Discontinuity Method, discontinuities in the rock are simulated using DDM elements for opposite surfaces of the discontinuity. This 2-D model can predict the fracturing processes including fracture initiation, fracture sliding/opening and fracture propagation. Both tensile (Mode I) and shear (Mode II) failure are considered. FRACOD considers the intact rock as a homogenous and flawless elastic body. Fractures are initiated as microcracks which propagate and coalesce into meso-cracks depending on the stress state and the location in the specimen.

Fractures are initiated as potential failure surfaces in the direction perpendicular to the tensile stress where the tensile stress reaches a pre-defined portion of the tensile strength for the intact rock. To describe shear failure, the cohesion and friction angle from the Mohr-Columb criterion are used to define the potential failure plane. A uniaxial compression test was simulated with the mechanical parameters from several physical tests where the specimens have been saturated with distilled water. The two main parameters used in the FRACOD model are the fracture toughness and the crack length. The initial crack length is determined from a numerical sensitivity analysis under these conditions with varying crack lengths.

In this simulation, the stress was monitored at the top of the specimen. The radial response was monitored at four locations on the vertical boundary. The reproduction of the behaviour of Ävrö granite indicated that, even at a relatively small confinement, the tensile fracture propagation is restrained which benefits the shear fractures, although shear failure seems to be the dominating failure mode even under this uniaxial loading. The post-peak behaviour of the rock is strongly affected by the loading configuration and material properties etc. The unstable fracturing process of Class II behaviour may also cease when a propagating fracture reaches another.

\section{The Finite Element Method (FEM) - Damage Expansion Model}

The essence of the damage model is that during microstructural failure, the local elastic modulus is given by the proportion of surviving elements multiplied by the original modulus 
value. In this method, the damage is increased by the additional strain energy, but is not changed during the unloading process. To be able to simulate fracture growth, the damage variable $\mathrm{D}$ is used (i.e. the proportion of damaged elements), which in turn is comprised of several damage parameters. These parameters describing the initial and progressive condition of the damage are derived from test results such as axial stress and strain, tangential strain, Young's modulus $\left(E_{0}\right)$ and Poisson's ratio at initial loading $\left(v_{0}\right)$.

Class II behaviour can be described via the excess energy being used only for fracture propagation, which makes the energy consumption a phenomenon localized to the fracture. The chemical effect is implemented as changes in the damage parameters derived from the results of the laboratory tests.

For the simulation of the chemically degraded specimens, three cases were tested: the specimens subjected to distilled water; the specimens subjected to saline water; and a case with intensified damage. To introduce heterogeneous energy consumption, an initial defect is pre-defined at the top of the specimen. The results for the three cases are shown in Figure 6. The decrease of the peak strength of the specimens subject to chemical degradation (seen in the right part of Figure 6) is likely a result of the decrease of the initial damage potential $\left(B_{0}\right)$. When comparing the post-peak behaviour of the cases, development of damage can be seen in the inner part of the specimen in the case of the distilled water; whereas, the damaged area developed in the outer part of the specimen resulting in intensified damage.

\section{Realism of the model simulations and discussion}

The overall motivation and the specific context of the modelling and testing programme was to evaluate the consistency and validity of four numerical models as applied to the simulation of the complete stress-strain curve for Ävrö granite tested in uniaxial compression. This work was intended as a pre-cursor to the potential use of the programs for more sophisticated modelling of the EDZ, i.e. to test them initially for simulating the simplest mechanical test on rock. The first approach to the results was to summarise the capabilities of the model and to consider their consistency. The models’ capabilities are listed in Table 4.

All the four modelling methods are able to reproduce Class I behaviour where the strain monotonically increases but it is harder to model the 'snap-back' Class II behaviour where the strain does not monotonically increase. The Ävrö granite is ultra-brittle and its behaviour in uniaxial compression is strongly Class II. In this exercise, and for the laboratory test conditions, the EPCA model, and the DDM technique represented by the FRACOD model managed to reproduce Class II behaviour. Although the exact test conditions and results could not be faithfully simulated, the general trends in mechanical behaviour were apparent from the models. The PFC model was not able to reproduce the Class II behaviour in its current form, but it is known that this can be achieved by using a numerical control technique similar to the lateral control used in the physical testing. The Damage Expansion Model was able to be adapted through the extraction of strain energy to approximate the Class II behaviour.

The discontinuous, inhomogeneous and inelastic nature of rock material can be simulated using the EPCA model, through the ability to incorporate initial failed elements, the use of the homogeneity index, the random seed of the mechanical parameters for cells and the possibility to implement several different control methods. It is crucial to identify the correct 
elemental yielding criterion in this method to be able to reproduce the behaviour of rock failure. The post-peak behaviour is controlled using the softening coefficient.

The PFC model, based on elemental discs or spheres, is also able to model the discontinuous, inhomogeneous and inelastic nature of the rock through the geometrical set-up and the interactions between the elemental particles. It shares the disadvantage common with the EPCA and damage models that the parameters of the numerical model are not directly measurable by laboratory tests. However, this modelling technique is particularly instructive in terms of the mechanisms that it demonstrates.

The same comments apply to the damage model approach which can be modified to incorporate a variety of features, but the 'sub-parameters' used to express the damage proportion for various conditions cannot be measured directly via laboratory tests.

The advantage of FRACOD is that many of the parameters can be directly measured by physical tests and they all have physical meanings, derived directly from Linear Elastic Fracture Mechanics (LFEM) together with sub-critical crack growth theory. Fracture initiation, stable and unstable states of fracture, peak strength and post-peak behaviour, including Class II behaviour, have been successfully modelled. An important advantage of this code is its capability to realistically model the brittle axial and lateral strain responses during the failure process.

All four research groups used their models in different ways in their attempts to simulate the effects of the different porewaters. It is clear that the potential is there for simulation and associated sensitivity studies of the chemical effects: the problem is to obtain appropriate parameters characterising the chemical effects at the micro-scale for input to the numerical models

\section{Conclusions from the research on modelling the mechanical behaviour of a rock element in the EDZ}

1. Testing the Ävrö granite under servo-controlled conditions in uniaxial compression indicated an ultra-brittle rock type with a strong Class II behaviour.

2. Limited testing of specimens under dry conditions, saturated with formation and saline waters, showed that the presence of porewater affected the elastic modulus, compressive strength, and geometry of the complete stress-strain curve.

3. Four numerical models were used to simulate the progressive structural collapse of the rock microstructure in uniaxial compression: an elasto-plastic cellular automaton, the 2-D Particle Flow Code, FRACOD based on the Displacement Discontinuity Method, and a Damage Expansion Model based on the Finite Element Method. All these models were useful in characterising and illustrating the trends in mechanical behaviour during the rock's microstructural breakdown. Moreover, all the models were eminently suitable for sensitivity studies to evaluate the influence of their respective supporting parameters. In this context, the work has further demonstrated the value of numerical models as a research tool. 
4. However, it was not possible for any of the models to explicitly model all the details of the specific Ävrö granite failure, i.e. to utilise the rock characteristics to successfully predict the exact complete stress-strain curves. This demands more detailed laboratory testing on the rock than generally can be obtained today. However, the current modelling capability is sufficient for engineering design.

\section{Modelling the EDZ and its evolution}

\section{Introduction}

In Part 2, the results of the international, multiple-code benchmark test (BMT) simulation study of coupled thermal, hydrological, mechanical and chemical (THMC) processes in the excavation disturbed zone (EDZ) around an emplacement drift of a hypothetical nuclear waste repository are summarized (see the companion paper in this Issue by Rutqvist et al. 2008). This simulation study focussed on mechanical responses and long-term chemomechanical effects that may lead to time-dependent changes in mechanical and hydrological properties in the EDZ. This may include processes such as creep, sub-critical crack growth, and healing of fractures that might cause 'weakening' or 'hardening' of the rock over the long term. Five research teams were studying this BMT using a wide range of model approaches, including boundary element, finite element, finite difference, particle mechanics, and cellular automata methods (Table 5 - note this includes one more Research Team than listed in Table 3 in Part 1).

An important part of this BMT was to investigate how these widely different approaches could be adapted and developed to include time-dependent processes to model the complex coupled THMC processes at various scales within or near the EDZ of an emplacement tunnel. Thus, this BMT was not a strictly defined problem for code-to-code comparison, but was rather designed to promote innovative model developments towards simulation of chemomechanical interactions with a future, fully coupled THMC modeling.

\section{BMT (Benchmark Test) description}

In this BMT, the coupled THMC processes of the EDZ were simulated for two sizes of model domains close to an emplacement tunnel: (1) a near-field model domain, and (2) a wall-block model domain (Rutqvist et al., 2008). The near-field model domain extends a few meters into the rock from the drift wall and allowed analysis of both the evolution and extent of the EDZ. The smaller sized wall-block model domain did not permit analysis of the extent of the EDZ, but rather it was used for detailed analysis of THMC processes within the EDZ.

\section{Scope of the BMT}

This BMT focuses on mechanical responses and long-term chemo-mechanical effects that may lead to time-dependent changes in mechanical and hydrological properties in the EDZ. The relatively small model sizes adopted for this BMT allow a very fine discretization of the 
model domain, which implies that the actual detailed physics of the rock failure process can be simulated.

The BMT included simulation of mechanical changes caused by chemo-mechanical interaction over the lifetime of an emplacement drift. More specifically, the following stages in the repository development were studied:

1) Excavation: Initial construction of the drift, which alters the mechanical, hydrological, and chemical circumstances

2) Pre-emplacement: A period when the excavation is left open as drying of the rock occurs, water flows through the fractures, and the chemistry changes

3) Post closure: A period after the waste and back-fill is emplaced, when the block is exposed to high temperature and thermal stress and (later) cooling and stress relief, and then establishment of an equilibrium over a long time period.

In this BMT, a pre-emplacement period of 10 years and a post-closure period of up to 100,000 years were considered. The aim was to simulate, as closely as possible, the THMC environment of the near-field and the EDZ over the 100,000-year lifetime of the repository. To simulate coupled THMC processes over 100,000 years, a much larger scale model than those suggested for this BMT would be required. Because the proposed near-field and the wall-block model domains only represent a small part of the repository system, the THMC environment had to be reproduced by specially designed, time-dependent boundary and interior conditions. For this BMT, the results from THM and THC analyses conducted within another DECOVALEX-THMC, Task D, FEBEX case, were utilized for assigning appropriate time-dependent boundary and interior conditions.

Because this BMT focused on mechanical changes in the EDZ, it was not necessary to model the actual evolution of thermal, hydrological, and chemical processes. Instead, the imported evolutions of thermal, hydrological and chemical conditions were only considered for their effects on the evolution of EDZ mechanical behaviour. For example, temperature, water saturation, and chemical potential may impact the long-term mechanical creep behaviour and may cause a long-term reduction in mechanical strength. One advantage with this approach was that the various mechanical models that had earlier been developed to model rock-failure processes in the previous Phase 2 of Task B (as described in Part 1 of this paper) could be utilized with relatively minor capability extension. The numerical models used for this BMT did not need capabilities to simulate heat transfer, flow or chemical transport. However, the models needed to be able to simulate the effects of thermal, hydrological, and chemical conditions on the evolution of the mechanical behaviour. For example, some models were extended to consider time-dependent (e.g., creep) processes, in which the time dependency could be a function of temperature, water saturation and chemical potential.

In this BMT, the excavation was assumed to occur instantaneously, whereupon the preemplacement period begins. The initial pre-excavation conditions were represented by in situ stresses, temperature and fluid pressure at a depth of $500 \mathrm{~m}$ in crystalline rocks. Specifically, data representing conditions at the Äspö Hard Rock Laboratory in Sweden correspond to an initial vertical stress of $13.2 \mathrm{MPa}$, a horizontal stress of $32.1 \mathrm{MPa}$, a temperature of $25^{\circ} \mathrm{C}$, and a fluid pressure of 5.0 MPa. The immediate effect of excavation was simulated by removing the support load on the lower boundary while increasing the stress on the right lateral boundary. At the same time, a fixed fluid pressure equal to atmospheric pressure was applied 
to the entire test block. After excavation of the drift, a transient analysis of the preemplacement period should be conducted for 10 years. For this simulation, stress, thermal, and hydrological boundary conditions were kept constant throughout the pre-closure.

The post-closure environment is simulated using a time-varying temperature, fluid pressure, and boundary stress. The time-varying temperature, fluid pressure, and boundary stresses are extracted from separate simulation results using the full drift-scale models of DECOVALEXTHMC, Task D (Rutqvist, 2008). As a first approximation, the emplacement of the waste and bentonite is assumed to take place instantaneously. A time-dependent increase in swelling pressure in the bentonite is simulated with a time-dependent normal stress at the bottom boundary. The simulation of postclosure environment should be conducted for over 100,000 years.

The initial pre-excavation conditions were represented by in situ stresses, temperature and fluid pressure at a depth of $500 \mathrm{~m}$ in crystalline rocks. That is an initial vertical stress of 13.2 $\mathrm{MPa}$, a horizontal stress of $32.1 \mathrm{MPa}$, a temperature of $25^{\circ} \mathrm{C}$, and a fluid pressure of $5.0 \mathrm{MPa}$. After excavation of the drift, a transient analysis were to be conducted including a 10-year pre-emplacement (operational) period followed by the post-closure period for up to 100,000 years.

\section{Fracture Pattern for Near-Field Model}

The fracture pattern to be used for Near-Field Model 2 was derived from fracture mapping at the Äspö Hard Rock Laboratory by Ann Bäckström of the Royal Institute of Technology, Sweden. Figure 7 presents the basic fracture pattern used as a starting point by all research teams in developing their model for analyzing the excavation disturbed zone. Note that this fracture pattern includes the effects of excavation (including damage by blasting and excavation induced stress redistribution) and was derived by a combination of fracture mappings in several Äspö tunnels.

\section{Overview of model approaches}

This Section presents comparison of the modeling approaches used by the different research team. Many different approaches were applied and adapted by the individual research teams and therefore it is a good opportunity to compare different approaches and the range of results produced. Each research team applied their codes and various modelling approaches on both the geometries, wall-block and near-field model domains, to analyze processes relevant to the evolution of the EDZ. The different approaches were used regarding

(1) Numerical methods and codes (Table 5)

(2) Discretisation of the problem

(3) Methods for modelling evolution of damage and permeability change

(4) Determination of input parameters relevant for prediction of the EDZ evolution

(5) Assessment of time-dependent effects 


\section{Numerical Methods and Codes}

The different numerical methods and codes used by the research teams are listed in Table 6. These numerical methods were selected not because one particular methods was deemed better than the other, but because these are the existing codes developed by or used by the respective research team in their regular scientific or engineering work. It is recognized that each numerical method may be suitable for analyzing different aspects of the EDZ evolution at different scales. A brief description of each code is presented below:

\section{TOUGH-FLAC (used by DOE team)}

For a coupled TOUGH-FLAC simulation, the two computer codes TOUGH2 (Pruess et al. 1999) and FLAC3D (Itasca Consulting Group 1997) have been coupled for the analysis of coupled multiphase flow, heat transport, and rock deformations in fractured porous media (Rutqvist et al. 2002). The TOUGH2 code is designed for hydrological analysis of multiphase, multicomponent fluid and heat transport, while FLAC3D is designed for rock and soil mechanics. In a TOUGH-FLAC simulation, the codes are coupled through external modules: one that calculates changes in effective stress as a function of multiphase pore pressure and thermal expansion, and one that corrects porosity, permeability, and capillary pressure as a function of stress. TOUGH-FLAC has been extensively applied in the Yucca Mountain Project (YMP) for the prediction of the evolution of coupled THM processes and for modeling the Yucca Mountain Drift Scale Test (Rutqvist et al. 2005).

\section{ROCMAS (used by DOE team)}

The ROCMAS code (ROCk Mass Analysis Scheme) is a finite-element code for analysis of coupled THM processes in saturated-unsaturated fractured porous media. It has been gradually developed and extended since the early 1980s at the Lawrence Berkeley National Laboratory, California (e.g. Noorishad et al. 1984). It is based on Biot's general effective stress theory, extended to nonisothermal and partially saturated media by Noorishad and Tsang (1996), Rutqvist et al. (2001a). It has been extensively applied to simulate bentoniterock and fractured rock problems within the DECOVALEX projects as well for analysis of coupled THM processes within the Swedish nuclear waste program (e.g, Rutqvist et al. 2001b).

\section{ECPA (used by CAS team)}

The ECPA code (Elasto-plastic Cellular Automaton) uses the concept of cellular automata inspired by self-organizing theory in biology. It postulates that the state in a cell is related to its neighbour and its behaviour is a function of its interaction with neighbouring individuals. Thus, the ECPA code is based the concept of cell, cell space, cell state, neighbourhood and updating rules. The EPCA code developed by the CAS includes: 1) heterogeneous material model (also it can be used to simulate the homogeneous case), 2) cellular automaton updating rules to obtain field states, 3) a yield criterion, 4) a cell elemental mechanical model for plasticity including loading-unloading criterion, and 5) acoustic emission. This code has been successfully used to simulate the failure process of heterogeneous rocks with and without 
consideration of hydro-mechanical coupling (Feng et al. 2006; Pan et al. 2006a; Pan et al. 2006b).

\section{THAMES (used by JAEA team)}

THAMES (Thermal, Hydraulic And MEchanical System analysis) is a finite-element code designed to simulate fully coupled thermal, hydraulic and mechanical behaviour in a fully or partially saturated medium. It has been developed and extended since the early 1980s, at Kyoto University, Japan (e.g , Ohnishi et al. 1987). Recent development of THAMES involves a three-dimensional coupled continuum model where the anisotropic permeability and stiffness of the fractured rock mass is derived from a combination of Oda's crack tensor theory and the Barton-Bandis joint model. This code has been extensively applied in the DECOVALEX project and within the Japanese nuclear waste program. Along with the study presented in this report, a continuum damage model is utilized and implemented and tested.

\section{PFC (used by SKI team)}

PFC (Particle Flow Code) is a code based on the discrete element method (DEM), is commercially available and widely used in rock engineering and academia (Potyondy and Cundall 2004). The system is modelled by a system of particles bonded at their contact points. The PFC represents damage or failure by breakage of bonds. PFC is particularly useful in modelling of damage and non-linear mechanical behaviour. All numerical simulations by PFC require proper calibration of micromechanical parameters, including bond strength and stiffness. Such calibrations may be done at both laboratory and field-scale depending on the intended application of the PFC code. In this study a two-dimensional version of the PFC codes was applied.

\section{FRACOD (used by the FRACOM team)}

The 2-dimensional boundary element code FRACOD is based on the Displacement Discontinuity Method (DDM) principles. A rock discontinuity (grain boundary, crack, joint etc.) is simulated by using DD elements to describe opposite surfaces of the discontinuity. The model predicts the explicit failure process including fracture initiation, fracture sliding/opening, fracture propagation and fracture coalescence. To take into account the small defects always present in the rock matrix, the code suggests new discontinuities to be implemented in the model. Rather than describing the micro-scale process in detail, the code focuses on whether a macro-fracture will form at a given location and stress state. Fracture propagation is modelled using the F- criterion suggested by Shen and Stephansson (1993). The F-criterion is based on Griffith's energy balance approach and it involves both shear and tensile failures. A creep model based on the sub-critical crack growth theory has been implemented in FRACOD to evaluate the time-dependent mechanical effects.

\section{Model simulation results and comparison}


Figure 8 for the near-field model presents contours of maximum and minimum principal stresses at 100 years in the early modelling stages. Further detailed comparisons can be found in Rutqvist et al., 2008. A large number of simulations were performed by each research team on the wall block-model and near-field model domains for studying the EDZ evolution. Here we focus on the results of the evolution of stress, failure and permeability, and on the assessment of time-dependent processes.

As an example, Figure 9 shows calculated fracture displacement and an assessment of the hydraulic conductivity distribution by the FRACOM team. The initial permeability in the fracture system before excavation is represented by green contours. The red contours indicate several order of magnitude increases in hydraulic conductivity. The result shows much increased hydraulic conductivity in a few points near fracture intersections. The large increase in hydraulic conductivity near the drift wall close to the top of the drift was caused by fracture opening after coalescence of fractures in that area. These changes occurred during the excavation phase with little change during the heating period. This shows how fracture permeability increases may be localized to fractures or fracture intersections, which may induce a very permeable flow channel along the drift.

As a further example, Figure 10 shows how the EDZ zone progresses for different steps of unloading near the drift wall to simulate a gradual excavation process. The zone of failure largely coincides with a zone of high deviatoric stress, whereas some tensile failure may also play a role, especially near the spring line of the drift. However, although failure was induced far into the rock, the shear and volumetric strain may still be limited in the mechanically constrained areas far away from the drift wall. Nevertheless, the results, if the induced shear failure produced significant shear dilation, could lead to additional permeability change that are permanent.

\section{Conclusions from the Part 2 research: Modelling the EDZ and its evolution}

- It has been demonstrated how widely different modelling approaches can be adapted to simulate the evolution of EDZ around a heat-releasing nuclear waste emplacement tunnel in fractured rock. Each modelling approach has its special capabilities for studying different aspects of the EDZ evolution at different scales.

- To make any reasonable assessment of the EDZ evolution, the models need to be supplied with proper input data. This includes laboratory data needed to determine parameters such a crack initiation and fracture toughness for the BEM method and for calibration of micromechanical parameters for the particle-mechanics method.

- If the models are properly calibrated and validated after excavation, a reasonable estimate can be made concerning how the EDZ will progress during the heating period after emplacement. 
- Predictions of chemically mediated time-dependent mechanical change over a 100,000-year period are still uncertain but could be conservatively bounded.

\section{Overall Conclusions and Recommendations}

1. The Ävrö granite was successfully tested under servo-controlled conditions in uniaxial compression, indicating an ultra-brittle rock type with a strong Class II behaviour. Limited testing of specimens under dry conditions, saturated with formation and saline waters, showed that the presence of porewater affected the elastic modulus, compressive strength, and geometry of the complete stress-strain curve.

2. Four numerical models were used to simulate the progressive structural collapse of the rock microstructure in uniaxial compression: an elasto-plastic cellular automaton, the 2-D Particle Flow Code, FRACOD based on the Displacement Discontinuity Method, and a Damage Expansion Model based on the Finite Element Method. All these models were useful in characterising and illustrating the trends in mechanical behaviour during the rock's microstructural breakdown. Moreover, all the models were eminently suitable for sensitivity studies to evaluate the influence of their respective supporting parameters, see Table 4.

3. It was not possible for any of the computer models to explicitly simulate all the details of the specific Ävrö microstructural granite failure, i.e. to utilise the rock characteristics to successfully predict the exact complete stress-strain curves. This demands more detailed laboratory testing on the rock than generally can be obtained today. However, the current modelling capability is sufficient for engineering design.

4. It has been demonstrated how widely different modelling approaches can be adapted to simulate the evolution of the EDZ around a heat-releasing nuclear waste emplacement tunnel in fractured rock. The EDZ fracture data from the Äspö Hard Rock Laboratory were successfully incorporated into the simulations. As a result, the important role of fractures and scale dependent (laboratory to tunnel scale) properties in evaluating the EDZ evolution has been identified, noting that the EDZ evolution during the thermal period was achieved by first calibrating a model to changes occurring during the excavation phase, also see the companion paper in this Issue by Rutqvist et al., 2008.

5. Scale dependent properties and how to capture critical changes in a few fractures around a drift (laboratory versus tunnel scale) are difficult and need further work. Also, time dependent strength degradation over 100,000 years is still uncertain and difficult to model. By definition, the simulations have to be done in the absence of any long-term time-dependent rock data.

6. Further studies are required of micromechanical rock breakdown with the aim of improved simulation, especially of the chemical features. Continued in situ studies with comprehensive measurements of permeability changes and their evolution during thermal stress changes are also required. 
7. Finally, the development of coupled THMC models should be pursued, i.e. models that can be used to better constrain chemically mediated changes in the mechanical properties.

\section{Acknowledgements}

This document has been written within the context of the DECOVALEX THMC 2004-2007 project (DEmonstration of COupled models and their VALidation against EXperiment). The authors are grateful to the Funding Organisations for their support and to Rolf Christiansson of SKB for his help and facilitation of the experimental work, both in the surface laboratory and in the underground Äspö Hard Rock Laboratory. The reviews of two anonymous referees helped the authors to improve the paper. Funding for the LBNL research team and author was provided to LBNL by the U.S. Department of Energy under Contract No. DE-AC02$05 \mathrm{CH} 11231$.

\section{References and Bibliography}

Davies C, Bernier F (Eds) (2005) Impact of the Excavation Disturbed or Damaged Zone (EDZ) on the Performance of Radioactive Waste Geological Repositories. Proceedings of the European Commission Cluster Conference and Workshop held in Luxembourg, 2003. EUR $21028 \mathrm{EN}$.

Fairhurst CE, Hudson JA (1999) Draft ISRM suggested method for the complete stress-strain curve for intact rock in uniaxial compression. Int J Rock Mech Min Sci 36:279-289.

Feng Xia-Ting, Pan Peng-zhi, Zhou Hui (2006) Simulation of rock microfracturing process under uniaxial compression using elasto-plastic cellular automata. Int J Rock Mech Min Sci 43: 1091-1108.

Hudson JA, Harrison JP (1997) Engineering rock mechanics - an introduction to the principles. Elsevier, Oxford.

Itasca Consulting Group Inc (1997) FLAC-3D Manual: Fast Lagrangian Analysis of Continua in 3 Dimensions-Version 2.0. Itasca Consulting Group Inc., Minnesota, USA.

Martino JB (Ed) (2003) The 2002 International EDZ Workshop on the Excavation Damage Zone - Causes and Effects. Report 06819-REP-01200-10105-R00, Atomic Energy of Canada Ltd.

Martino, JB, Martin CD (Eds) (1996) EDZ Winnipeg Workshop on Designing the Excavation Disturbed Zone for a Nuclear Repository in Hard Rock. Canadian Nuclear Society.

Noorishad J, Tsang C-F (1996) ROCMAS-simulator: A Thermohydromechanical Computer Code. In Stephansson O, Jing L, Tsang, C-F (Eds) Coupled Thermo-hydro-mechanical Processes of Fractured Media. Developments in Geotechnical Engineering, Elsevier, 79: 551-558. 
Noorishad J, Tsang C-F,Witherspoon PA (1984) Coupled thermal-hydraulic-mechanical phenomena in saturated fractured porous rocks: numerical approach. J Geophys Res 89: 10365-10373.

Ohnishi Y, Shibata H, Kobayashi A (1987) Development of finite element code for the analysis of coupled thermo-hydro-mechanical behavior of a saturated-unsaturated medium. In Tsang C-F (ed) Coupled Processes Associated with Nuclear Waste Repositories: 551-557.

Okubo S, Nishimatsu Y (1985) Uniaxial compression testing using a linear combination of stress and strain as the control variable. Int J Rock Mech Min Sci Geomech Abstr 22(5):323330.

Pan Peng-zhi, Feng Xia-ting, Hudson JA. (2006)a. Simulations of Class I and Class II curves by using a linear combination of stress and strain as the control method and elasto-plastic cellular automata . Int J Rock Mech Min Sci 43: 1109-1117.

Pan Peng-zhi, Feng Xia-ting, Zhou Hui ( 2006)b. Simulation of rock fracturing in an HM coupling environment using a cellular automaton. In Proc GEOPROC2006 Int Sym: $2^{\text {nd }}$ Int conf on coupled thermo-hydro-mechanical-chemical processes in geosystems and engineering, HoHai University, Nanjing, China: 503-508.

Posiva (2006) Expected evolution of a spent nuclear fuel repository at Olkiluoto, (eds.) Pastina B, Hellä P. Posiva Report 2006-05, see www.posiva.fi

Poteri A., Laitinen, M (1999) Site-to-canister scale flow and transport in Hästholmen, Kivetty, Olkiluoto and Romuvaara. Posiva Report 99-15: 156p

Potyondy DO, Cundall PA (2004) A bonded-particle model for rock. Int J Rock Mech Min Sci 42: 1329-1364.

Pruess K, Oldenburg C, Moridis G (1999) TOUGH2 User’s Guide, Version 2.0, Report LBNL-43134, Lawrence Berkeley National Laboratory, Berkeley, Calif.

Rutqvist J, Barr D, Datta R, Gens A, Millard M, Olivella S, Tsang CF, Tsang Y. (2005) Coupled thermal-hydrological-mechanical analysis of the Yucca Mountain Drift Scale Test comparison of field results to predictions of four different models. Int J Rock Mech Min Sci 42: 680-697.

Rutqvist J, Börgesson L, Chijimatsu M, Kobayashi A, Nguyen TS, Jing L, Noorishad J, Tsang C-F (2001a) Thermohydromechanics of partially saturated geological media governing equations and formulation of four finite element models. Int J Rock Mech Min Sci 38:105-127.

Rutqvist J, Börgesson L, Chijimatsu M, Nguyen TS, Jing L, Noorishad J, Tsang C-F (2001b) Coupled thermo-hydro-mechanical analysis of a heater test in fractured rock and bentonite at Kamaishi Mine - Comparison of field results to predictions of four finite element codes. Int J Rock Mech Min Sci 38: 129-142. 
Rutqvist J, Wu Y-S, Tsang C-F, Bodvarsson G (2002) A modeling approach for analysis of coupled multiphase fluid flow, heat transfer, and deformation in fractured porous rock. Int $\mathrm{J}$ Rock Mech Min Sci 39: 429-442.

Rutqvist J, Bäckström A, Chijimatsu M, Feng Xia-Ting, Pan Peng-zhi, Hudson JA, Jing L, Kobayashi A, Koyama T, Lee Hee-Suk, Huang Xiao-Hua, Rinne M, Shen Bao-tang (2008) A benchmark simulation study of the long-term EDZ evolution of geological nuclear waste repositories. Envir Geol:this issue.

Shen B, Stephansson O (1993) Numerical analysis of mixed mode-I and mode-II fracture propagation. Int J Rock Mech Min Sci 30:861-867.

SKB (2006) Long-term safety for KBS-3 repositories at Forsmark and Laxemar - a first evaluation. Main report of the SR-Can project. Swedish Nuclear Fuel and Waste Management Co (SKB), Stockholm, Sweden. SKB Tech Rep TR-06-09.

Tsang C-F, Bernier F, Davies C (2005) Geohydromechanical processes in the Excavation Damaged Zone in crystalline rock, rock salt, and indurated and plastic clays - in the context of radioactive waste disposal. Int J Rock Mech Min Sci 42, 1: 109-125. 


\section{Figures}

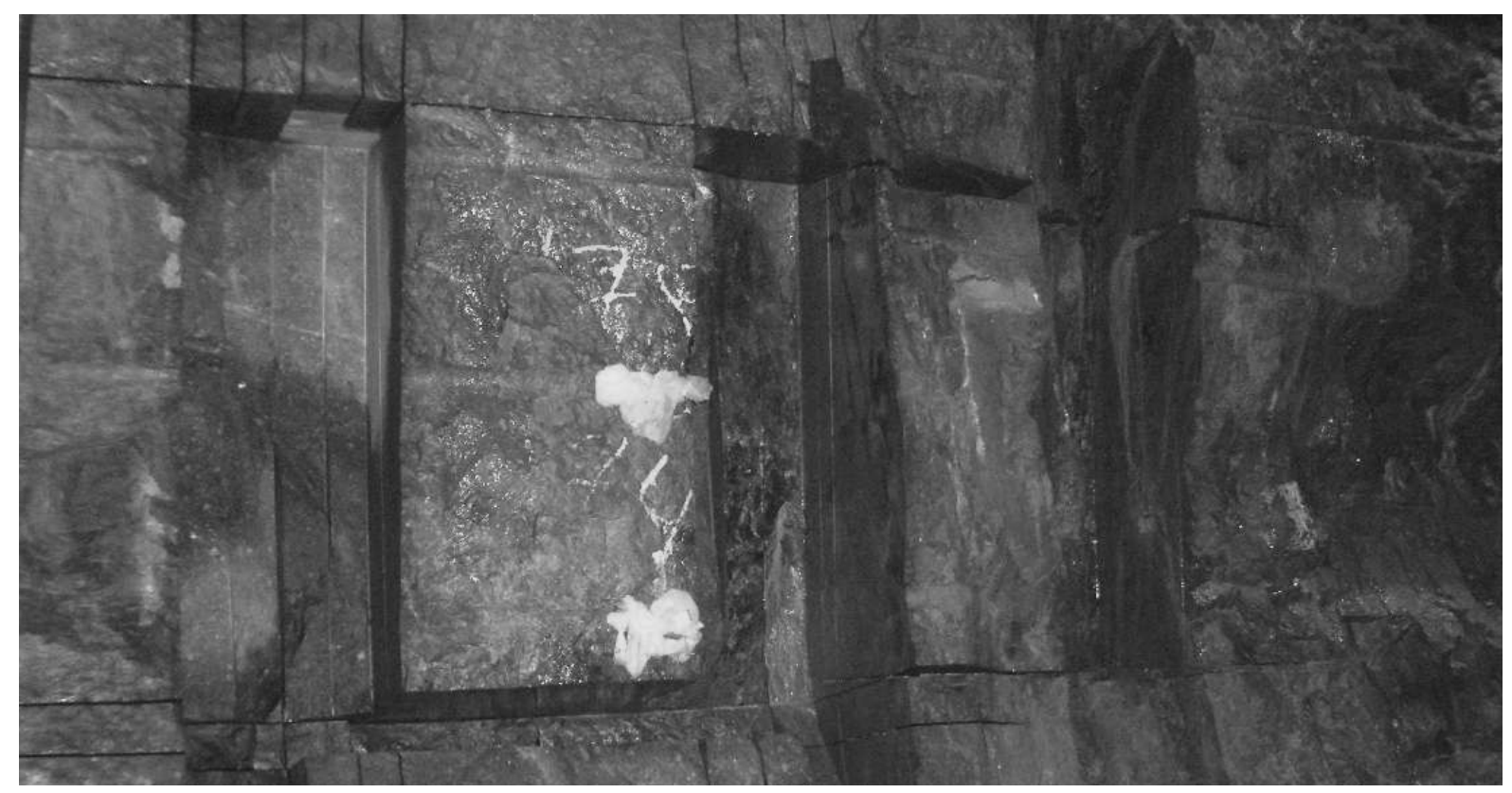

(a)

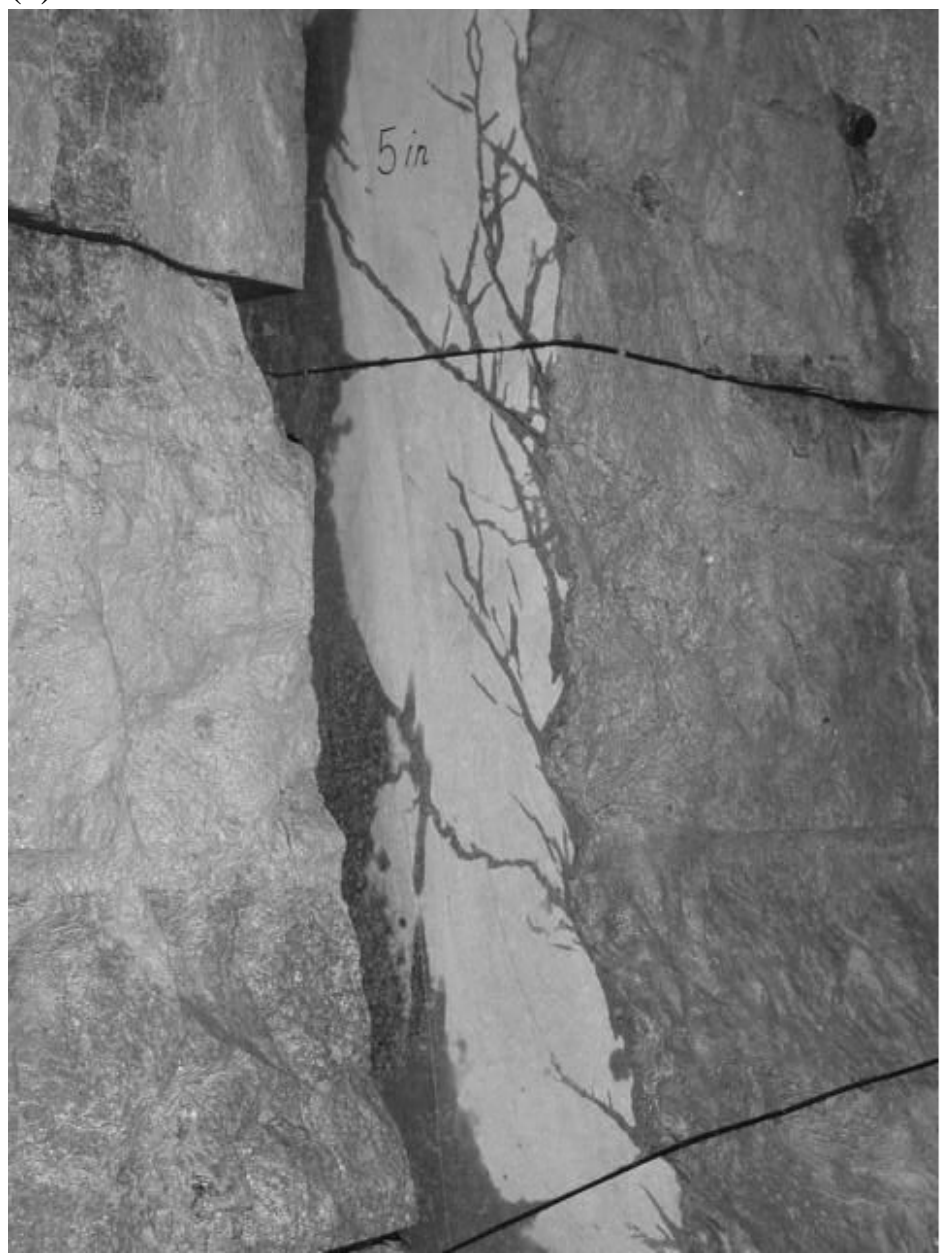

(b)

Figure 1: (a) Sections cut from the tunnel wall at the Äspö Hard Rock Laboratory, Sweden. (b) View of the cut section showing Excavation Damaged Zone (EDZ) fractures. 


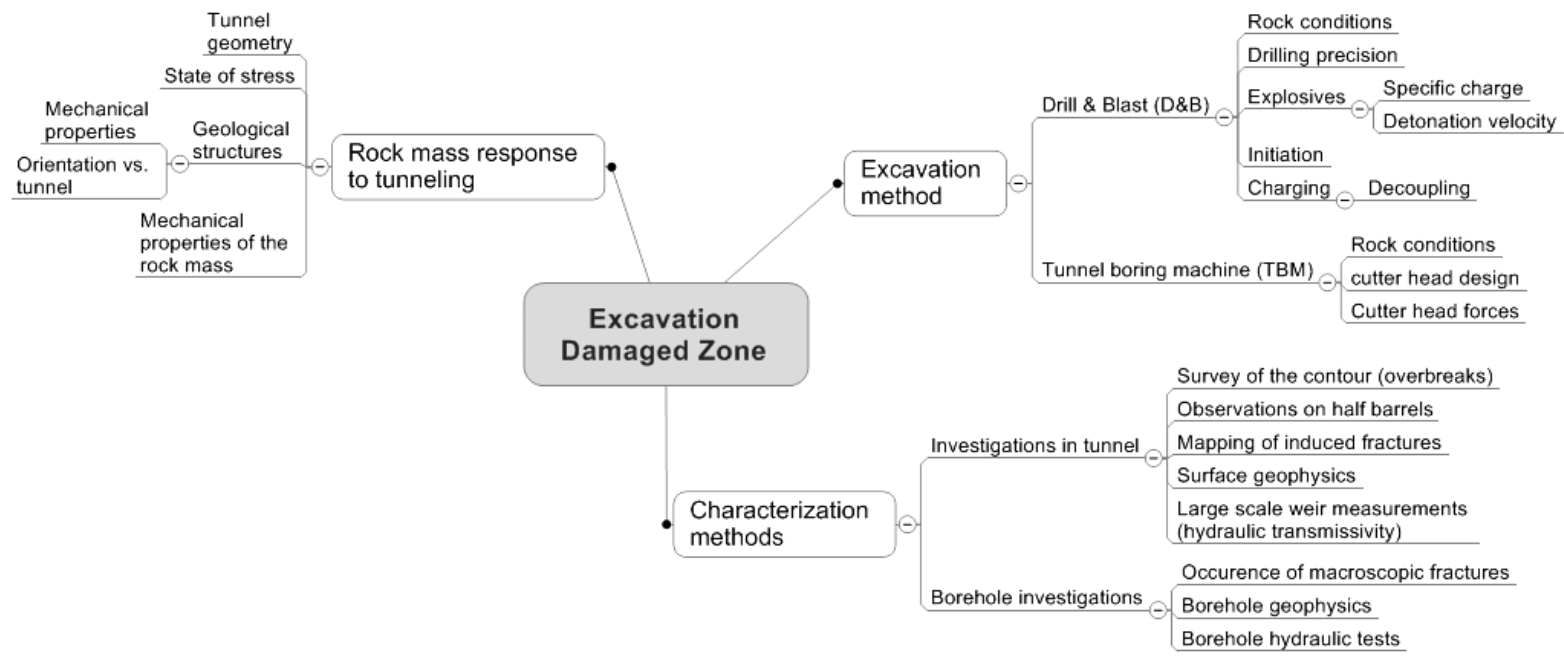

Figure 2: Summary of the factors relating to the rock mass response to tunnelling, the excavation method, and characterisation methods.

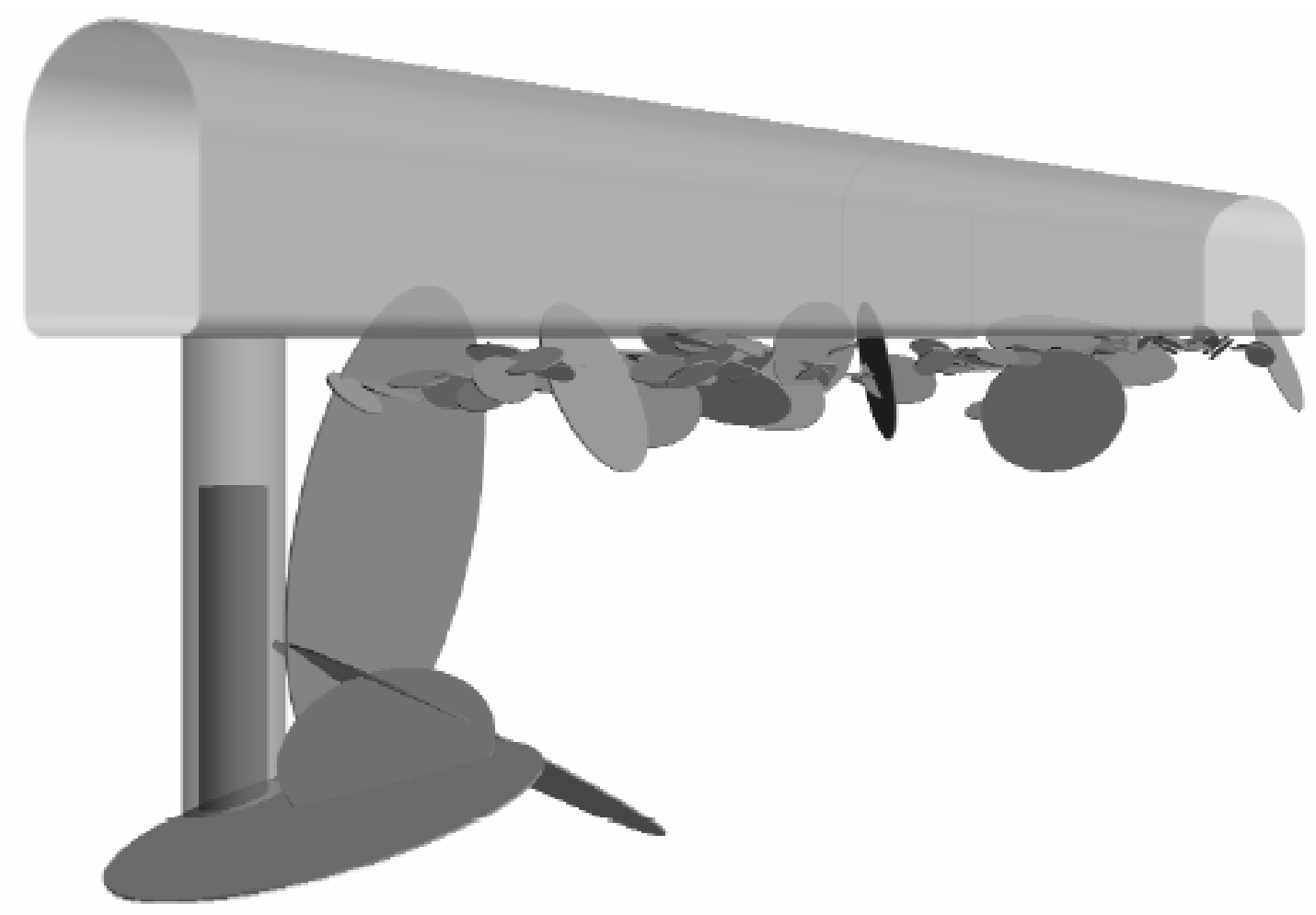

Figure 3: Possibility of a connected fracture network in the EDZ region (from Poteri and Laitinen, 1999Figure 4: Stress-strain curve (Class II type - does not monotonically increase in axial strain) for the Ävrö granite - which is ultra-brittle. 


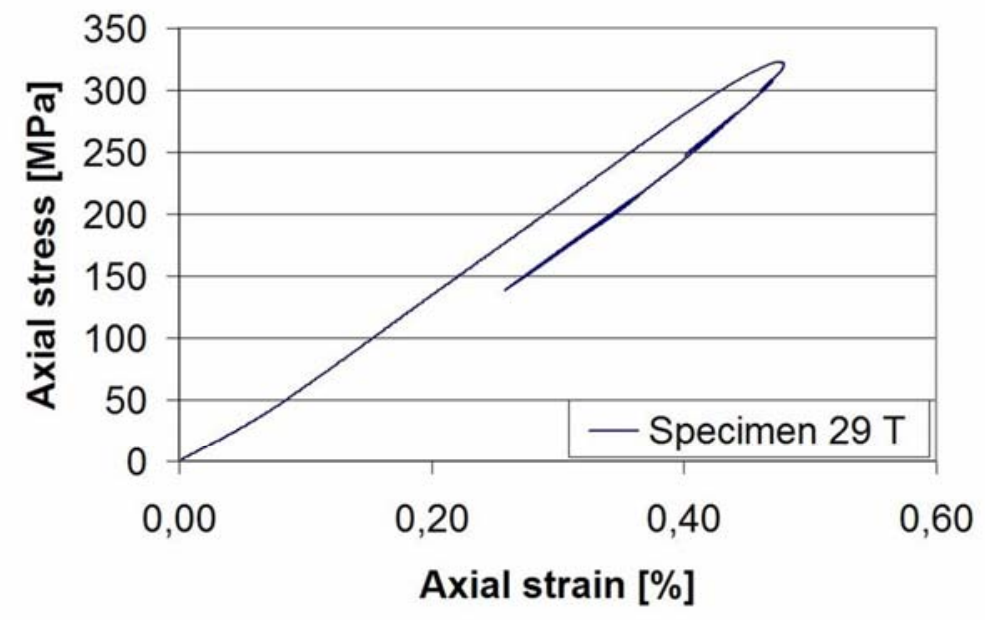

Figure 4: Stress-strain curve (Class II type - does not monotonically increase in axial strain) for the Ävrö granite - which is ultra-brittle.

Dry sample (sample D_18)

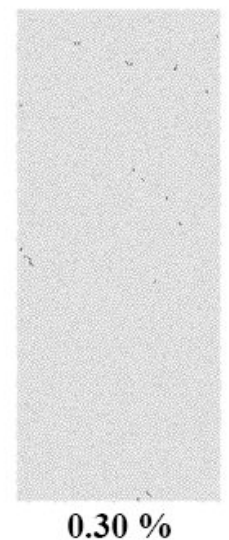

(18)

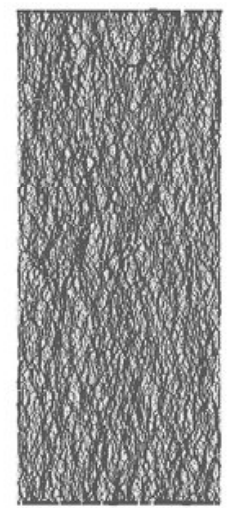

$0.30 \%$

$(0.4521)$

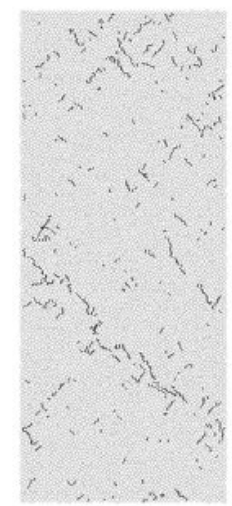

Peak

(546)

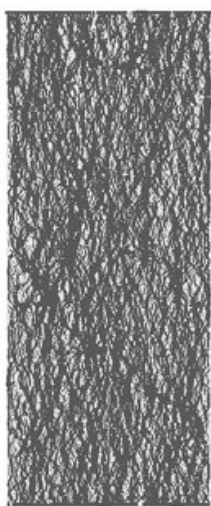

Peak

(0.6201)

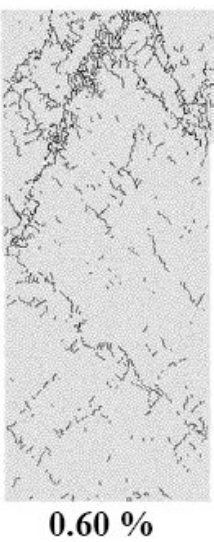

(1571)

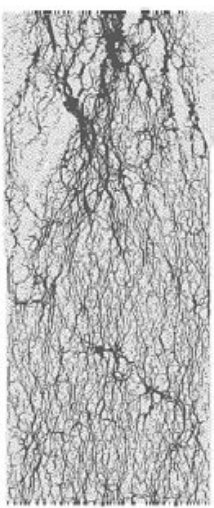

$0.60 \%$

$(0.6990)$
Formation water 90days (sample F_90_20)

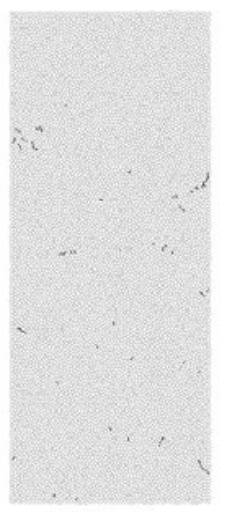

$0.30 \%$

(63)

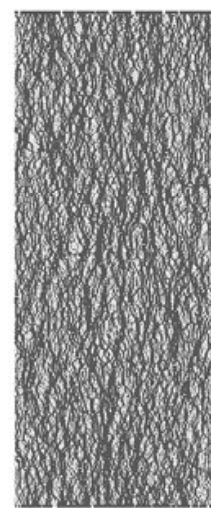

$0.30 \%$

$(0.4847)$

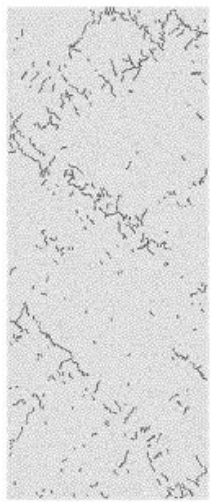

Peak

(737)

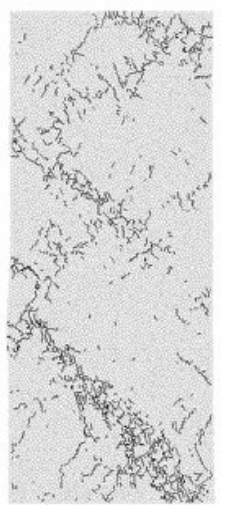

$0.60 \%$

(1738)

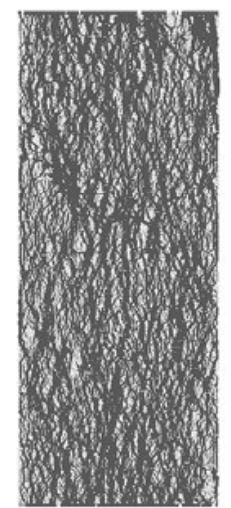

Peak

(0.9193)

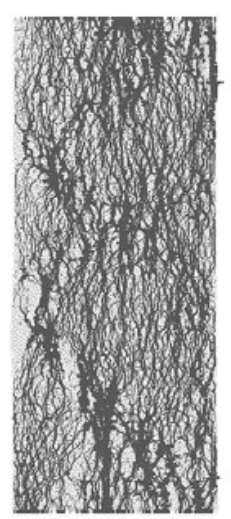

$0.60 \%$

(1.012)

Figure 5: PFC modelled fracture evolution (top) and contact force distribution (below) at: before peak ( $0.3 \%$ strain), at peak, and after peak ( $0.6 \%$ strain). The values in parentheses are the number of the micro-cracks (top) and maximum contact force, MN (below). 


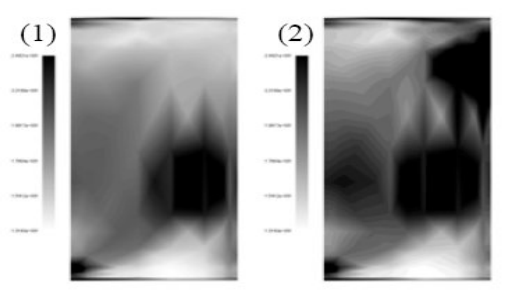

(a) Damage variable distribution

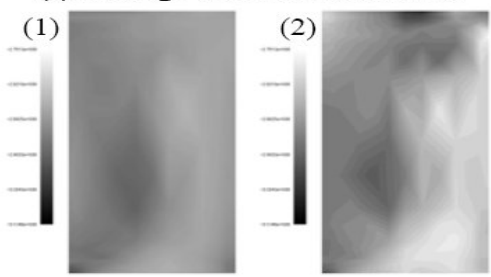

(b) Axial stress distribution

(1) Distilled water

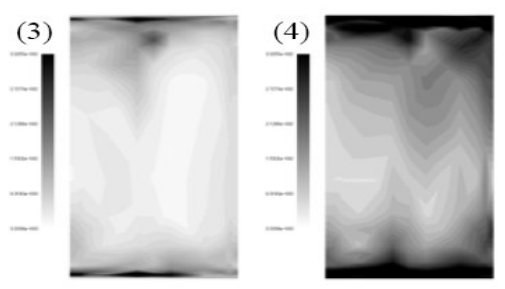

(a) Damage variable distribution

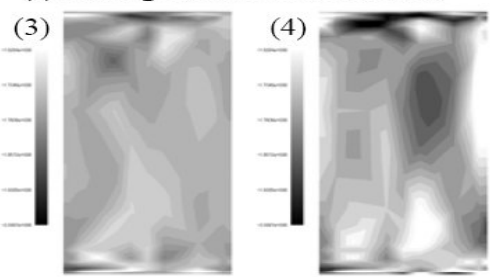

(b) Axial stress distribution

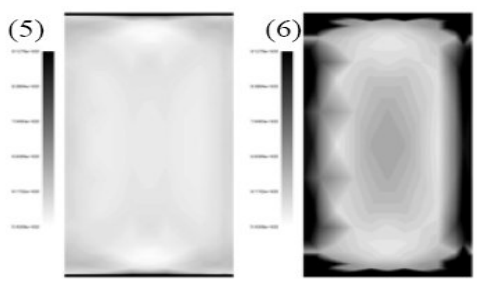

(a) Damage variable distribution

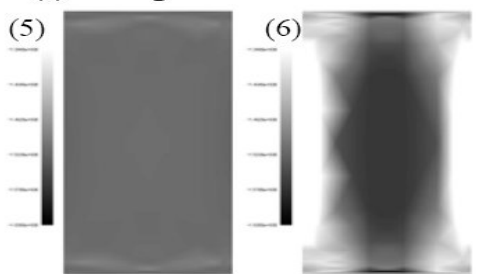

(b) Axial stress distribution

(3) Intensified damage

Figure 6: The results of the three FEM cases simulated by the Damage Model, where the distribution of the damage and the axial stress are seen in (a) with large damage and high axial stress represented by increased grayscale and the calculated stress-strain relations are shown to the right (b). The numbers in the two parts refer to the situation just before the peak and just after the peak for the different cases.

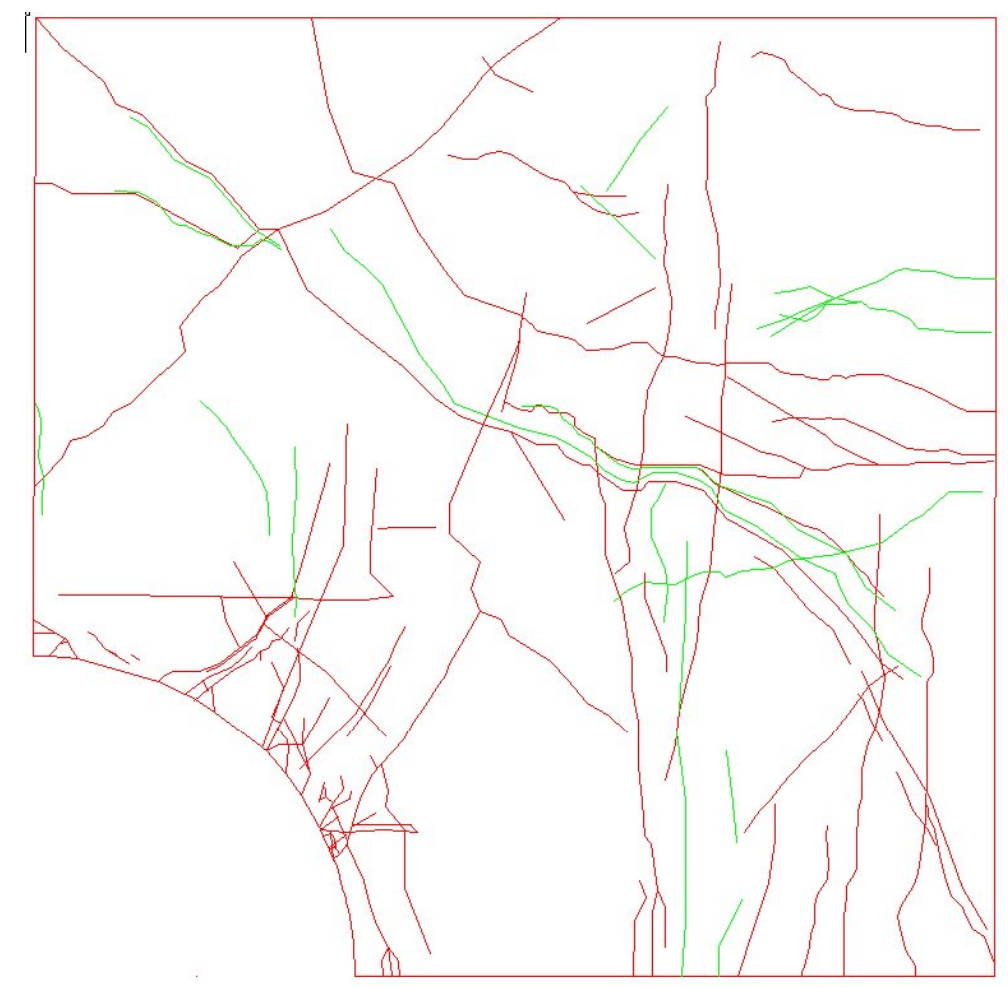

Figure 7: Fracture pattern used as a starting point by each research team. Open fractures are coloured red and filled fractures are green. 

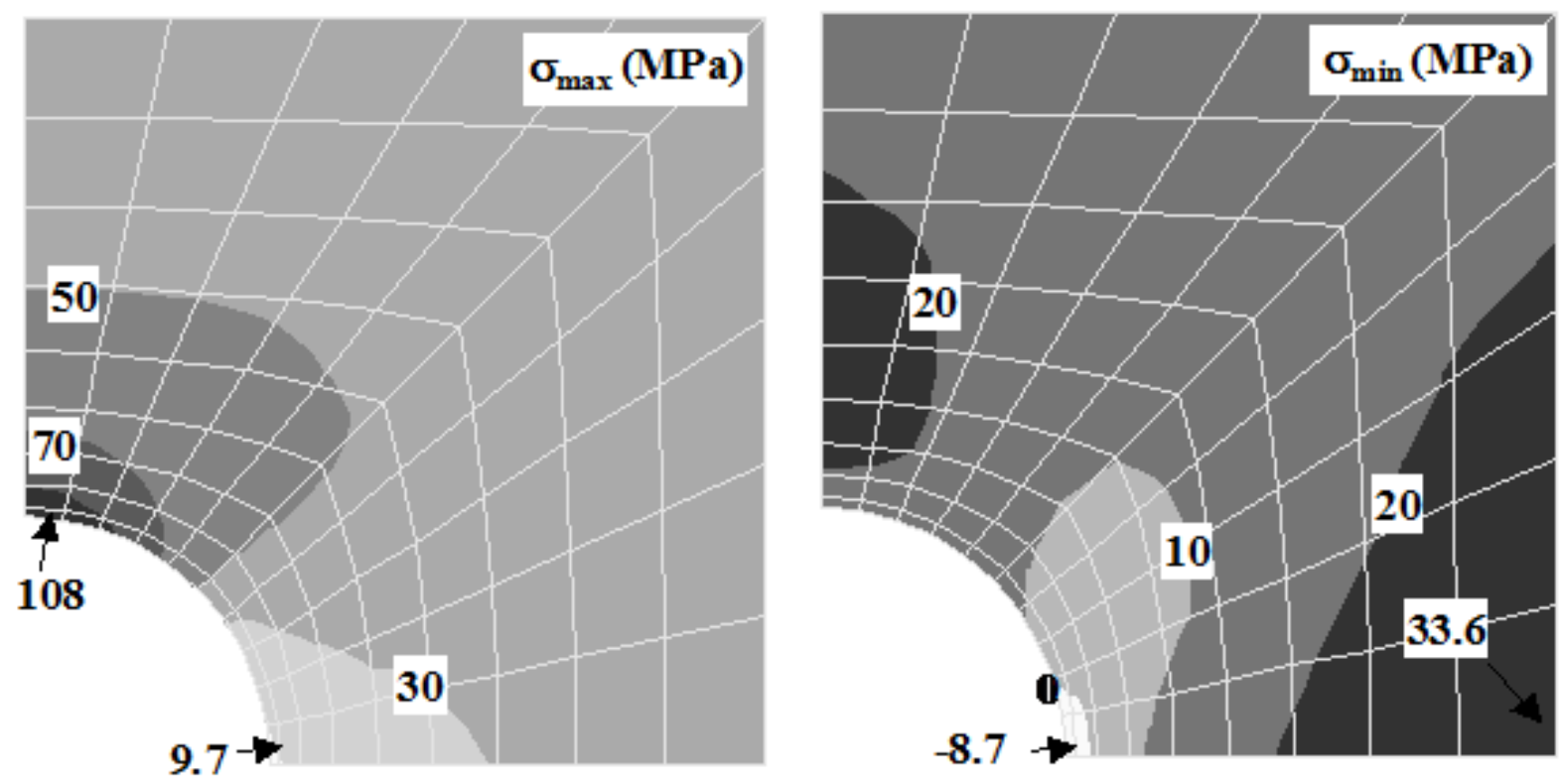

Figure 8. Simulation results from the DOE1 model of maximum and minimum compressive principal stresses at 100 years for Stage 1 of the simulations.

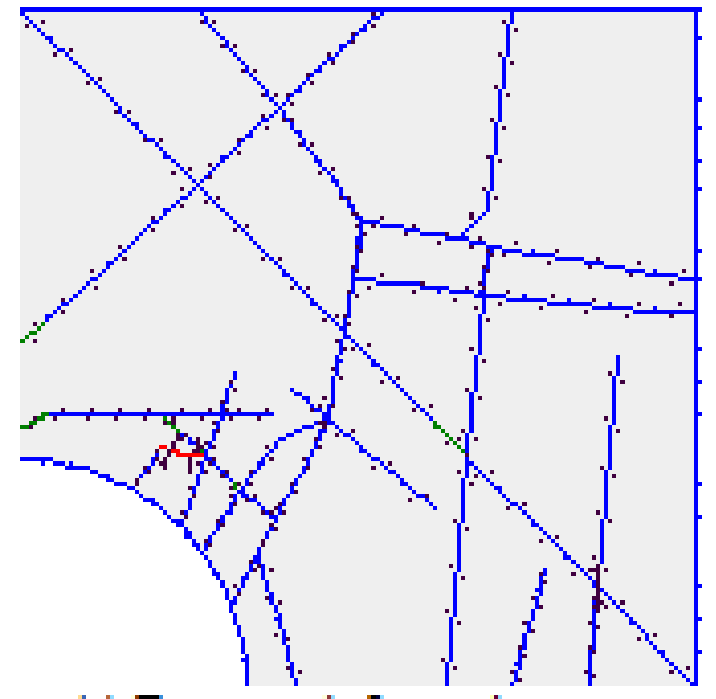

(a) Fracture deformation

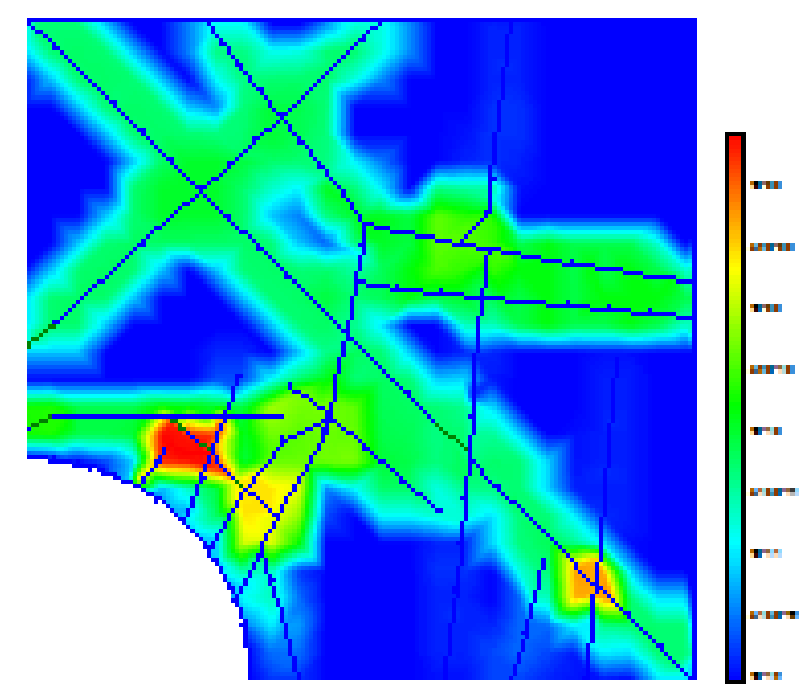

(b) Estimated hydraulic conductivity

Figure 9: Fracture deformation and associated changes in fracture hydraulic conductivity (FRACOM2 model). 


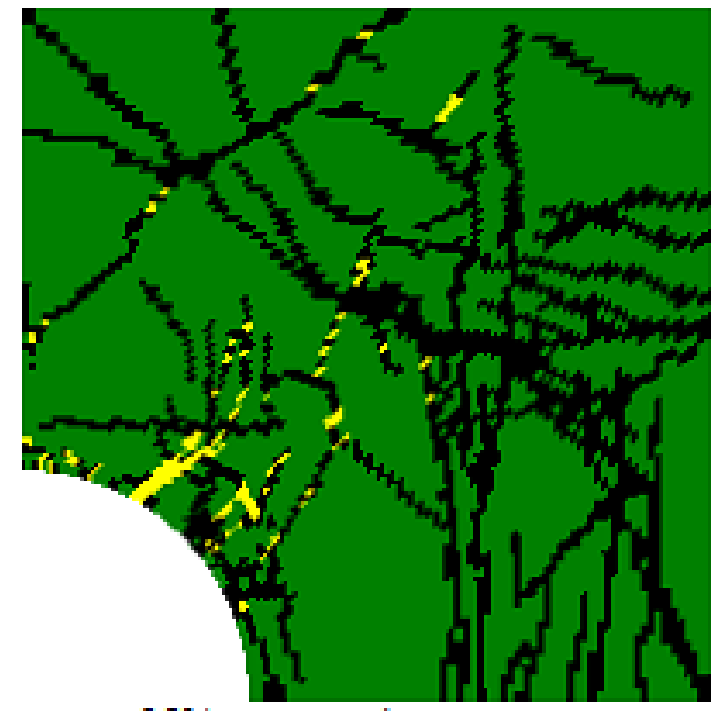

$25 \%$ excavated

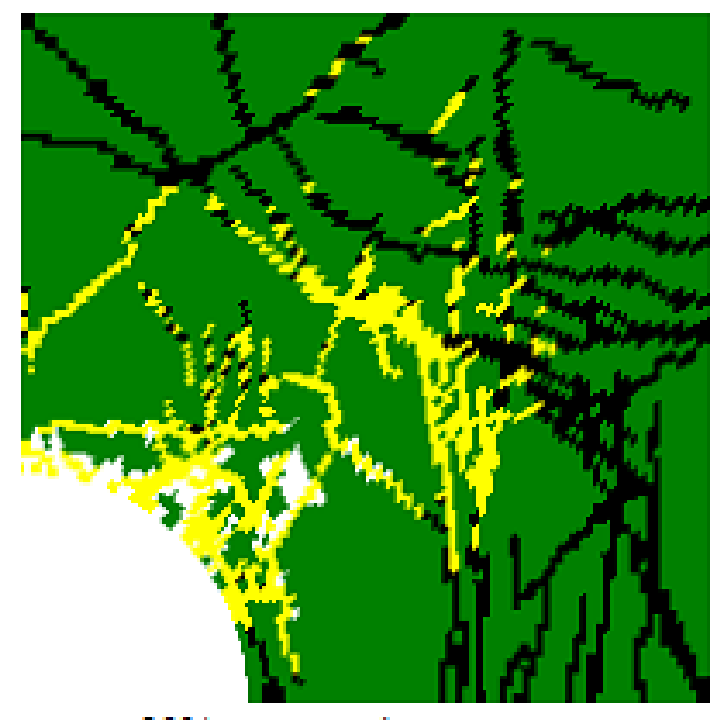

$80 \%$ excavated

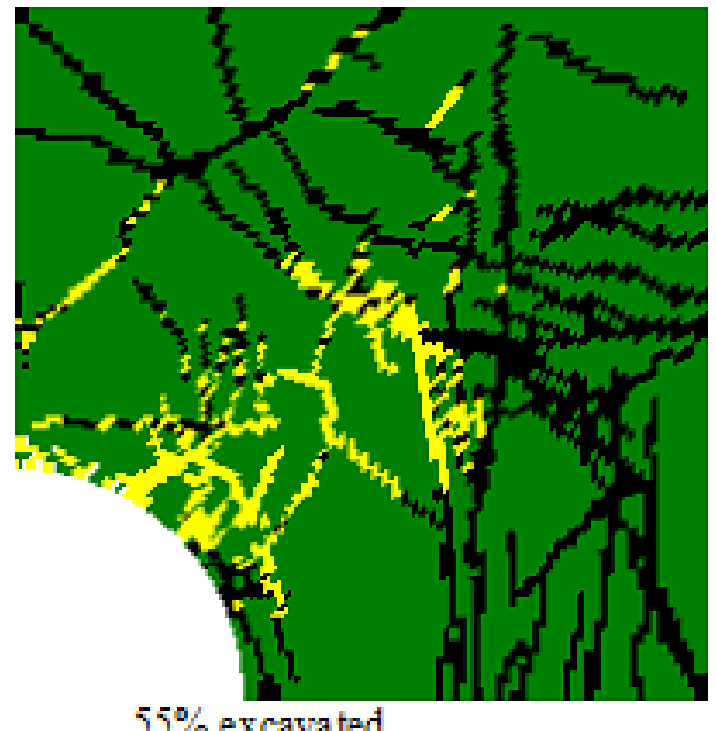

$55 \%$ excavated

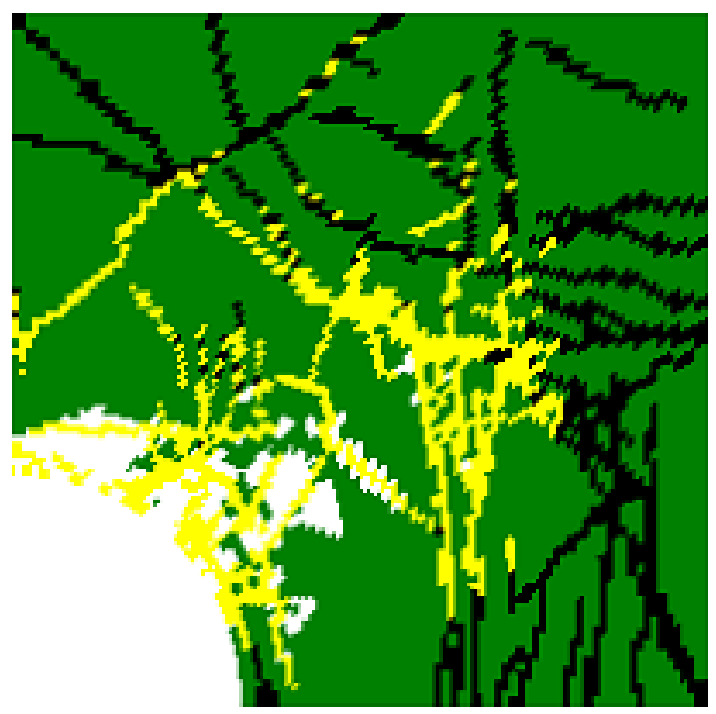

$100 \%$ excavated

Figure 10: Evolution of failure represented by Mohr-Coulomb yielding in matrix rock (with contours) and fractures (yellow contour) calculated with the CAS2 model. 


\section{Tables}

Table 1: Characterising the EDZ (Excavation Damaged Zone): estimation methods and uncertainties associated with the different measurement methods, with measures for reducing the uncertainties.

\begin{tabular}{|c|c|c|}
\hline Measurement method & Uncertainty aspect & Mitigating the uncertainty \\
\hline \multicolumn{3}{|c|}{ Tunnel scale } \\
\hline $\begin{array}{l}\text { Acoustic Emission (AE) } \\
\text { during tunnelling (requires } \\
\text { extensive pre-excavation } \\
\text { installation) }\end{array}$ & $\begin{array}{l}\text { The location of the AE } \\
\text { event }\end{array}$ & $\begin{array}{l}\text { Use no less than three } \mathrm{AE} \\
\text { sensors in the vicinity of the } \\
\text { event. }\end{array}$ \\
\hline $\begin{array}{l}\text { Seismic investigations (P- } \\
\text { wave and S-wave } \\
\text { velocities) in tunnel wall }\end{array}$ & $\begin{array}{l}\text { Saturated, unsaturated } \\
\text { conditions in tunnel wall, } \\
\text { interpretation of the results }\end{array}$ & $\begin{array}{l}\text { Verification of conditions } \\
\text { and structures by drilling }\end{array}$ \\
\hline Radar methods & $\begin{array}{l}\text { Saturated, unsaturated } \\
\text { conditions in tunnel wall, } \\
\text { interpretation of the results, } \\
\text { salinity of water, electric } \\
\text { objects - minerals, } \\
\text { installations, orientation of } \\
\text { structure }\end{array}$ & $\begin{array}{l}\text { Verification of the } \\
\text { structures by drilling, } \\
\text { hydrochemical analysis of } \\
\text { water, general investigation } \\
\text { of fracture minerals, remove } \\
\text { disturbing installations, } \\
\text { measurements from } \\
\text { different orientation }\end{array}$ \\
\hline $\begin{array}{l}\text { Geological observations of } \\
\text { fractures, rock types, water } \\
\text { flow }\end{array}$ & $\begin{array}{l}\text { One-dimensional or } \\
\text { generally two-dimensional } \\
\text { information, and the } \\
\text { limitation of sampling area }\end{array}$ & $\begin{array}{l}\text { Geometrically link the } \\
\text { information to the three- } \\
\text { dimensional structure, } \\
\text { increase area of sampling }\end{array}$ \\
\hline Dye penetration test & $\begin{array}{l}\text { See previous. Also, the } \\
\text { conditions for penetration } \\
\text { might create bias }\end{array}$ & $\begin{array}{l}\text { See previous. Also, several } \\
\text { locations for sampling }\end{array}$ \\
\hline $\begin{array}{l}\text { Geometrical measurement } \\
\text { of the excavation }\end{array}$ & Only surface information & $\begin{array}{l}\text { Additional complementary } \\
\text { investigations into the wall, } \\
\text { as in drillholes }\end{array}$ \\
\hline $\begin{array}{l}\text { Mapping of visible trace of } \\
\text { blastholes }\end{array}$ & $\begin{array}{l}\text { Qualitative investigation, } \\
\text { strongly depending on rock } \\
\text { type/explosives }\end{array}$ & $\begin{array}{l}\text { Geometrical information of } \\
\text { the drillhole position from } \\
\text { the collar }\end{array}$ \\
\hline $\begin{array}{l}\text { Monitoring water pressure } \\
\text { in probe holes }\end{array}$ & $\begin{array}{l}\text { Packer position, packer } \\
\text { closure effectiveness }\end{array}$ & $\begin{array}{l}\text { Alternative positioning of } \\
\text { measurement, large amount } \\
\text { of measurements }\end{array}$ \\
\hline Water flow into tunnel & Capturing the volume & $\begin{array}{l}\text { Compartmentalisation of } \\
\text { the inflow }\end{array}$ \\
\hline $\begin{array}{l}\text { Pressure build-up tests in } \\
\text { probe holes }\end{array}$ & $\begin{array}{l}\text { Manual water flow rate } \\
\text { measurements, ground } \\
\text { water pressure } \\
\text { measurements (insufficient } \\
\text { evacuation of air, etc.), } \\
\text { evaluation of test /Almén \& } \\
\text { Stenberg, 2005/. }\end{array}$ & $\begin{array}{l}\text { In-situ calibration, } \\
\text { information of the related } \\
\text { status in the pressure } \\
\text { reference system, correct } \\
\text { ground water model /Almén } \\
\text { \& Stenberg, 2005/. }\end{array}$ \\
\hline
\end{tabular}




\begin{tabular}{|c|c|c|}
\hline In-situ gas permeability & $\begin{array}{l}\text { Small volume sampled, } \\
\text { interference of rock matrix }\end{array}$ & $\begin{array}{l}\text { Several samples, both in- } \\
\text { situ and on specimens of the } \\
\text { rock type x-rayed and found } \\
\text { to be without fractures }\end{array}$ \\
\hline \multicolumn{3}{|c|}{ Core boreholes-core logging } \\
\hline $\begin{array}{l}\text { Geological mapping of } \\
\text { cores }\end{array}$ & $\begin{array}{l}\text { 'One-dimensional’ data, } \\
\text { core loss and orientation of } \\
\text { core }\end{array}$ & $\begin{array}{l}\text { Core in different directions, } \\
\text { alternative orientation } \\
\text { identification }\end{array}$ \\
\hline $\begin{array}{l}\text { Seismic investigations } \\
\text { (P-wave and S-wave } \\
\text { velocities) in core }\end{array}$ & $\begin{array}{l}\text { Determination of onset of } \\
\text { P- and S-wave velocities, } \\
\text { pseudo-elastic parameters } \\
\text { calculation, arrival time of } \\
\text { signal, position in rotational } \\
\text { measurements }\end{array}$ & $\begin{array}{l}\text { Larger amount of sampling } \\
\text { in the same conditions, } \\
\text { verification against } \\
\text { geological data, alternative } \\
\text { orientation identification }\end{array}$ \\
\hline $\begin{array}{l}\text { Borehole television logging } \\
\text { (BIPS) }\end{array}$ & $\begin{array}{l}\text { Colour, dark wall reflection, } \\
\text { orientation and deformation } \\
\text { of image due to eccentricity } \\
\text { of borehole, depth location } \\
\text { due to cable elasticity }\end{array}$ & $\begin{array}{l}\text { Control of light source, } \\
\text { clean borehole, alternative } \\
\text { orientation measurement, } \\
\text { correction of geometry } \\
\text { using image analysis, } \\
\text { information of elasticity } \\
\text { parameters for cables }\end{array}$ \\
\hline Directional borehole radar & $\begin{array}{l}\text { Salinity of water, electric } \\
\text { objects - minerals, } \\
\text { orientation of structure }\end{array}$ & $\begin{array}{l}\text { Hydrochemical analysis of } \\
\text { water, general investigation } \\
\text { of fracture minerals, } \\
\text { measurements from } \\
\text { different orientation }\end{array}$ \\
\hline \multicolumn{3}{|c|}{$\begin{array}{l}\text { Laboratory scale } \\
\text { (measurements on core samples from different depths in the tunnel wall) }\end{array}$} \\
\hline $\begin{array}{l}\text { Microscopic and SEM } \\
\text { investigations of thin- } \\
\text { sections }\end{array}$ & $\begin{array}{l}\text { Proportion of fractures } \\
\text { induced by sample } \\
\text { preparation, two- } \\
\text { dimensional investigation }\end{array}$ & $\begin{array}{l}\text { Control of preparation, } \\
\text { several samples }\end{array}$ \\
\hline X-ray (tomography) & $\begin{array}{l}\text { Resolution, small volume of } \\
\text { specimen }\end{array}$ & $\begin{array}{l}\text { Increase number of } \\
\text { specimens }\end{array}$ \\
\hline $\begin{array}{l}\text { AE onset under uniaxial } \\
\text { compressive loading }\end{array}$ & $\begin{array}{l}\text { Controlling of loading and } \\
\text { displacement, location of } \\
\text { AE event }\end{array}$ & $\begin{array}{l}\text { Determining appropriate } \\
\text { loading conditions, enough } \\
\text { AE sensors surrounding the } \\
\text { specimen, with optimal } \\
\text { sensitivity }\end{array}$ \\
\hline $\begin{array}{c}\text { Porosity measurements } \\
\text { (PMMA, He-gas diffusion) }\end{array}$ & $\begin{array}{l}\text { Imaging of pores, two- } \\
\text { dimensional information }\end{array}$ & $\begin{array}{l}\text { Image analysis, many } \\
\text { samples }\end{array}$ \\
\hline $\begin{array}{c}\text { Dye penetration (UV- } \\
\text { sensitive resin into } \\
\text { fractures) }\end{array}$ & $\begin{array}{l}\text { Penetration of dye, } \\
\text { evaluation of area and } \\
\text { structures observed }\end{array}$ & $\begin{array}{l}\text { optimise preparatory } \\
\text { method }\end{array}$ \\
\hline
\end{tabular}


Table 2: Mechanical properties of the rock specimens as tested with different chemical conditions (dry in the first case and after 90 days immersion in the last three cases).

\begin{tabular}{ccccc}
\hline Specimen group & $\begin{array}{c}\text { Young's } \\
\text { modulus } \\
\text { (E) [GPa] }\end{array}$ & $\begin{array}{c}\text { UCS } \\
\text { [MPa] }\end{array}$ & $\begin{array}{c}\text { +ve slope of } \\
\text { the Class II } \\
\text { post failure } \\
\text { locus [GPa] }\end{array}$ \\
\hline \multirow{2}{*}{ Dry } & Min. & 70.4 & 273.9 & 87 \\
& Mean & 71.6 & 302.3 & 95 \\
& Max. & 72.7 & 335.8 & 111 \\
\hline \multirow{2}{*}{ Distilled } & Min. & 67.5 & 249.4 & 85 \\
& Mean & 68.5 & 270.5 & 101 \\
& Max. & 69.4 & 287.4 & 111 \\
\hline \multirow{3}{*}{ Formation } & Min. & 66.1 & 232.8 & 84 \\
& Mean & 66.6 & 248.5 & 97 \\
& Max. & 67.2 & 264.2 & 115 \\
\hline \multirow{2}{*}{ Saline } & Min. & 65.1 & 220.4 & 82 \\
& Mean & 66.8 & 249.4 & 141 \\
& Max. & 67.8 & 277.0 & 209 \\
\hline
\end{tabular}


Table 3: Research teams and numerical tools for simulating the complete stress-strain curve for rock (Part 1 of the paper)

\begin{tabular}{|l|l|}
\hline \multicolumn{1}{|c|}{ Research Team } & Numerical Simulator/Approach \\
\hline \hline $\begin{array}{l}\text { CAS: Chinese Academy of } \\
\text { Sciences' Research Team }\end{array}$ & $\begin{array}{l}\text { Elasto-plastic Cellular Automaton } \\
\text { (EPCA) }\end{array}$ \\
\hline FRACOM: FRACOM Ltd, Finland & $\begin{array}{l}\text { FRACOD boundary element (BEM) } \\
\text { code with discrete fracture } \\
\text { propagation }\end{array}$ \\
\hline $\begin{array}{l}\text { JAEA: Japan Atomic Energy } \\
\text { Kyoto University }\end{array}$ & $\begin{array}{l}\text { Damage expansion model using finite } \\
\text { element analysis. }\end{array}$ \\
\hline $\begin{array}{l}\text { SKI: Swedish Nuclear Power } \\
\text { Inspectorate's Research Team: } \\
\text { Royal Institute of Technology, } \\
\text { Stockholm }\end{array}$ & $\begin{array}{l}\text { PFC distinct element particle flow } \\
\text { code }\end{array}$ \\
\hline \hline
\end{tabular}


Table 4: Summary of the capabilities of the four numerical models used in this study for modelling the complete stress-strain curve for intact rock. The first four completed rows represent capabilities that were used in the current modelling; the last six italicised rows represent the further model capabilities.

\begin{tabular}{|c|c|c|c|c|}
\hline $\begin{array}{c}\text { Model } \\
\text { Parameter }\end{array}$ & $\begin{array}{c}\text { Elasto-Plastic } \\
\text { Cellular } \\
\text { Automaton } \\
\text { model }\end{array}$ & PFC model & $\begin{array}{c}\text { Finite element } \\
\text { damage } \\
\text { expansion } \\
\text { model }\end{array}$ & $\begin{array}{c}\text { FRACOD - DDM } \\
\text { model }\end{array}$ \\
\hline $\begin{array}{l}\text { Inhomogeneity, } \\
\text { rock material } \\
\text { and cracks }\end{array}$ & $\begin{array}{l}\text { Yes, using } \\
\text { Weibull } \\
\text { distribution of } \\
\text { properties }\end{array}$ & $\begin{array}{c}\text { Yes different } \\
\text { particle sizes, } \\
\text { different contact } \\
\text { bond strengths and } \\
\text { stiffnesses }\end{array}$ & $\begin{array}{l}\text { Yes, different } \\
\text { damage for } \mathrm{D} \text {, } \\
\text { but intact part is } \\
\text { homogeneous }\end{array}$ & $\begin{array}{l}\text { Yes, different } \\
\text { intact rock } \\
\text { properties and } \\
\text { presence of cracks }\end{array}$ \\
\hline $\begin{array}{l}\text { Type of failure } \\
\text { (Class I) }\end{array}$ & Yes & Yes & Yes & Yes \\
\hline $\begin{array}{l}\text { Type of failure } \\
\text { (Class II) }\end{array}$ & Yes & $\begin{array}{l}\text { Not implemented } \\
\text { for this work, } \\
\text { but possible }\end{array}$ & $\begin{array}{l}\text { Yes, but } \\
\text { indirectly }\end{array}$ & Yes \\
\hline Chemistry & $\begin{array}{l}\text { Yes, via element } \\
\text { changes }\end{array}$ & $\begin{array}{l}\text { Yes, via changing } \\
\text { the particle bonds }\end{array}$ & $\begin{array}{l}\text { Yes, via } \\
\text { intensified } \\
\text { damage }\end{array}$ & $\begin{array}{l}\text { Yes, via changing } \\
\text { crack propagation } \\
\text { velocity (Charles’ } \\
\text { law) }\end{array}$ \\
\hline Anisotropy & $\begin{array}{l}\text { Yes, via cell } \\
\text { property } \\
\text { specification }\end{array}$ & $\begin{array}{c}\text { Yes, via the particle } \\
\text { specification }\end{array}$ & $\begin{array}{l}\text { Yes, via } \\
\text { specification of } \\
\text { the elements }\end{array}$ & $\begin{array}{c}\text { Yes, via the } \\
\text { stiffness values, } \\
\text { crack orientations } \\
\text { and densities, } \\
\text { different } \\
\text { directional fracture } \\
\text { toughnesses }\end{array}$ \\
\hline Pore Pressure & $\begin{array}{c}\text { Yes, via effective } \\
\text { stress }\end{array}$ & Yes & $\begin{array}{l}\text { No, but could be } \\
\text { implemented in } \\
\text { the future }\end{array}$ & $\begin{array}{c}\text { Yes, via application } \\
\text { of static pressure in } \\
\text { the fracture, but } \\
\text { uncoupled }\end{array}$ \\
\hline Time dependency & $\begin{array}{l}\text { Yes, via changing } \\
\text { the properties with } \\
\text { model steps, also } \\
\text { can use viscous } \\
\text { elements }\end{array}$ & Yes & $\begin{array}{l}\text { Yes, but has not } \\
\text { yet been done }\end{array}$ & $\begin{array}{c}\text { Yes, via crack } \\
\text { propagation } \\
\text { velocity (Charles' } \\
\text { law) }\end{array}$ \\
\hline Fractures & Yes & Yes & $\begin{array}{l}\text { Yes, but have to } \\
\text { be considered } \\
\text { separately }\end{array}$ & $\begin{array}{c}\text { Yes, several } \\
\text { fracture properties } \\
\text { can be } \\
\text { incorporated }\end{array}$ \\
\hline Temperature & Yes & Yes & Yes, but not yet & Not directly \\
\hline
\end{tabular}


Table 5: Research teams and numerical simulators used for the EDZ simulation (Part 2 of the paper).

\begin{tabular}{|l|l|}
\hline \multicolumn{1}{|c|}{ Research Team } & \multicolumn{1}{|c|}{ Numerical Simulator/Approach } \\
\hline \hline $\begin{array}{l}\text { DOE: U.S. Department of Energy's } \\
\text { Research Team: Lawrence Berkeley } \\
\text { National Laboratory (LBNL) }\end{array}$ & $\begin{array}{l}\text { TOUGH-FLAC simulator using finite } \\
\text { difference method (FDM) }\end{array}$ \\
\cline { 2 - 2 } $\begin{array}{l}\text { CAS: Chinese Academy of Sciences' } \\
\text { Research Team }\end{array}$ & $\begin{array}{l}\text { Elasto-plastic Cellular Automaton } \\
\text { (EPCA) }\end{array}$ \\
\hline $\begin{array}{l}\text { FRACOM: FRACOM Ltd, Finland } \\
\text { JAEA: Japan Atomic Energy } \\
\text { Agency's Research Team, including } \\
\text { Kyoto University }\end{array}$ & $\begin{array}{l}\text { FRACOD boundary element (BEM) } \\
\text { code with discrete fracture propagation }\end{array}$ \\
\hline $\begin{array}{l}\text { SKI: Swedish Nuclear Power } \\
\text { Inspectorate's Research Team: Royal } \\
\text { Institute of Technology, Stockholm }\end{array}$ & PFC distinct element particle flow code \\
\hline
\end{tabular}


Table 6: Brief description of models used for simulating the near-field model (EDZ) domain.

\begin{tabular}{|c|c|c|}
\hline $\begin{array}{l}\text { Model } \\
\text { Identification }\end{array}$ & Grid & Description \\
\hline $\begin{array}{l}\text { DOE1 } \\
90 \text { elements }\end{array}$ & & $\begin{array}{l}\text { Homogenous continuum model for linear elastic } \\
\text { analysis of Stage } 1 . \text { FEM model based on Biot's theory } \\
\text { accounting for internal thermal strain and poro-elastic } \\
\text { stress (ROCMAS code). }\end{array}$ \\
\hline $\begin{array}{l}\text { DOE2 } \\
7068 \text { elements }\end{array}$ & & $\begin{array}{l}\text { Heterogeneous continuum model in which fractures are } \\
\text { represented by continuum elements with reduced } \\
\text { modulus and strength for analysis of Stage } 1,2 \text { and } 3 \text {. A } \\
\text { FEM model based on Biot's theory accounting for } \\
\text { internal thermal strain and poro-elastic strain } \\
\text { (ROCMAS code). }\end{array}$ \\
\hline $\begin{array}{l}\text { CAS1 } \\
90 \text { cells }\end{array}$ & & $\begin{array}{l}\text { Homogenous continuum model for linear elastic and } \\
\text { elasto-plastic analyses. Elasto-plastic Cellular Automata } \\
\text { (EPCA) model accounting for internal thermal strain } \\
\text { and poro-elastic strain (EPCA code). }\end{array}$ \\
\hline $\begin{array}{l}\text { CAS2 } \\
7068 \text { cells }\end{array}$ & & $\begin{array}{l}\text { Heterogeneous continuum model in which fractures are } \\
\text { represented by continuum elements with reduced } \\
\text { modulus and strength. Elasto-plastic Cellular Automata } \\
\text { (EPCA) model accounting for internal thermal strain } \\
\text { and poro-elastic stain (EPCA code). }\end{array}$ \\
\hline $\begin{array}{l}\text { CAS3 } \\
15996 \text { cells }\end{array}$ & & \\
\hline $\begin{array}{l}\text { SKI1 } \\
12757 \text { particles }\end{array}$ & & $\begin{array}{l}\text { A distinct element particle flow model which simulates } \\
\text { the rock mass through undeformable particles with } \\
\text { deformable and breakable bonds (PFC code). This a } \\
\text { homogeneous model. Internal thermal and poro-elastic } \\
\text { strain not considered. }\end{array}$ \\
\hline $\begin{array}{l}\text { SKI2 } \\
12757 \text { particles }\end{array}$ & & $\begin{array}{l}\text { A distinct element particle flow model which simulates } \\
\text { the rock mass a through rigid particles with deformable } \\
\text { and breakable bounds (PFC code). In this } \\
\text { heterogeneous model, fractures are represented by } \\
\text { breaking bonds along the trace of the fractures. Fracture } \\
\text { network simplified to only include open fractures and } \\
\text { they are assumed to be perfectly planar. Internal } \\
\text { thermal and poro-elastic strain not considered. }\end{array}$ \\
\hline
\end{tabular}




\begin{tabular}{|l|l|l|}
\hline FRACOM1 & & $\begin{array}{l}\text { A homogenous boundary element (BEM) model } \\
\text { (FRACOD) for linear elastic analysis of Stage 1. } \\
\text { Internal thermal and poro-elastic strain not considered. }\end{array}$ \\
\hline FRACOM2 & & $\begin{array}{l}\text { Beundary element (BEM) code with discrete fracture } \\
\text { propagation (FRACOD). Model with discrete fractures } \\
\text { in a homogenous rock matrix. Fracture network } \\
\text { simplified to include a subset of major fractures and are } \\
\text { assumed to be perfectly planar along their trace. } \\
\text { Internal thermal and poro-elastic strain not considered. }\end{array}$ \\
\hline $\begin{array}{l}\text { JAEA1 } \\
\text { 144 elements }\end{array}$ & $\begin{array}{l}\text { FEM with continuum damage model in which change in } \\
\text { mechanical behaviour due to the growth of damage } \\
\text { (cracks) in material and associated permeability change } \\
\text { is considered. Internal thermal and poro-elastic strain } \\
\text { not considered. }\end{array}$ \\
\hline
\end{tabular}

